\title{
İlâhî Fiillerin Nedenliliği Bağlamında Tefsir-Kelâm İlişkisi
}

\author{
Muhammed Coşkun**
}

\begin{abstract}
The Relationship Between Tafsīr (Quranic Exegesis) and Kalām (Theology) in the Context of the Causality of Divine Acts

Throughout its long history, the works of tafsir (Qur'anic exegesis) have been substantially influenced by discussions carried out within the discipline of kalām (theology). Particularly, this influence might be observed in post-classical tafsir texts. To a certain extent, this is understandable. However, to understand the Qur'anic text in its own context, in its integrity as a text and in an extra-textual context ( $n u z \bar{u} l)$, it seems necessary to consider it through a perspective that is free of other considerations. In this paper we evaluate the influence of kalām on the tafsir works within the context of the commentaries made on Surah Anbiyā 21/23 in particular; this verse is associated with the cause of the divine acts. We also designate alternative meanings given to this particular verse within the textual and extra-textual contexts, and finally discuss the possibility of associating these interpretations with contemporary discussions of kalām.
\end{abstract}

Key words: Quranic exegesis/tafsīr, theology/kalām, cause, divine acts.

\section{Konu ve Çerçeve}

Kelâm tartışmalarının sonucu olarak teşekkül eden temel kabullerin tefsirdeki güçlü etkisi, müfessirler tarafından satır aralarında sıklıkla ifade edilmektedir. Fahreddin er-Râzî (ö. 606/1210), kelâm mezheplerinin muhkem ve müteşâbihleri belirlerken temel kabulleri uyarınca hareket edip bu kabullere uyan âyetleri muhkem, diğerlerini ise müteşâbih saydıklarını ve bunun hem Mu'tezile hem de Ehl-i sünnet tarafından benimsenen ortak bir tavır

* Yaptıkları değerlendirmelerle makaleye katkıda bulunan kıymetli dostlarım Ercan Alkan'a ve Hayrettin Nebi Güdekli’ye teșekkür ederim.

** Yrd. Doç. Dr., Marmara Üniversitesi İlahiyat Fakültesi (muhammed.coskun@marmara.edu.tr). 
olduğunu kaydetmektedir. ${ }^{1}$ Bu çerçevede Mútezilî müfessir Ebû Müslim elİsfahânîyi (ö. 322/934), mezhebine muvafik âyetleri muhkem, diğerlerini ise müteşâbih addetmekle suçlayan ve yadırgayan Fahreddin er-Râzî, ${ }^{2}$ tartışmanın sonunda, bunun aslında herkes (cumhûrü’n-nâs) tarafından sergilenen ortak bir tavır olduğunu ifade etmektedir. ${ }^{3}$

Fahreddin er-Râzînin sözünü ettiği husus, daha önce Gazzâlî (ö.505/1111) tarafından da gerekçeleriyle birlikte dile getirilmiştir. el-Müstasfẩnın başında kelâm ilmini bütün dinî ilimler içinde en kapsamlı ve aslî konuma yerleştiren ve tefsir dahil bütün ilimlerin kelâma tâbi olduğunu kaydeden ${ }^{4}$ Gazzâlî, kelâm ilminin dindeki küllî kaideleri belirlemesi açısından kuşatıcı ve tümel konumda olduğunu, diğer ilimlerin ise kelâm tarafından çizilen çerçeve içerisinde hareket ettiklerini ifade etmektedir. Gazzâlînin bu ifadeleri, kelâm ilmine sahip olmadığ bir yetkiyi atfetmek ya da tefsir ve diğer disiplinlerin alanını daraltmak şeklinde değil, açık bir durum tespiti olarak anlaşılmalıdır. Çünkü tarihsel gerçeklik içerisinde kelâm ilminin dinî ilimler arasında, küllî kaideleri belirleyici, dinî düşüncenin genel çerçevesini inşa edici bir konuma sahip olduğu açıktır. ${ }^{5}$ Bununla beraber kelâmın bu konumu, onun tefsir üzerinde belirleyici bir işlev görmesini gerektiren ya da bunu mantıksal olarak zorunlu kılan bir durum değildir. Kelâm, İslâm düşüncesinin ontolojik ve epistemolojik çerçevesini çizmesi açısından tefsir ve diğer disiplinlerden daha üst düzeyde konumlanmış olsa da, başka bir açıdan ilimler arasındaki hiyerarşide tefsir ve hadis gibi ilimlerin öncelenmesi de mümkündür. Tefsir ve hadis disiplinleri, Kur'an'da ve Hz. Peygamber'in ifade ya da uygulamalarında içkin olan mâna ve maksadı başka herhangi bir kabulün etkisi altında olmadan salt tefsir (anlama) faaliyeti çerçevesinde tespit etmeye çalışması, nüzûl ve vürût bağlamı içerisinde ilk muhataplar tarafından idrak edilmiş olan -otantik- anlamı araması ve elde ettiği sonucu kelâm ve fikıh gibi disiplinlere veri olarak sunması açısından, kelâm ve fikıh disiplinlerini "belirleyici/önceleyici” konumda olabilir. En azından tefsir ve hadis alanlarının birer veri kaynağ nin olmasını beklemek, kelâmın bu iki alan üzerindeki belirleyiciliği kadar mâkul görünmektedir. ${ }^{6}$ Ancak bu ilimlerin arasındaki hiyerarşide bilfiil ta-

$1 \quad$ Bk. Fahreddin er-Râzî, Mefâtîhu'l-gayb, VII, 182; benzer ifadeler için ayrıca bk. Kādî Abdülcebbâr, Müteşâbihü'l-Kur'ân, I, 8.

2 Bk. Fahreddin er-Râzî, Mefâtî̀hu'l-gayb, VII, 188.

3 Bk. Fahreddin er-Râzî, Mefâtîhu'l-gayb, VII, 189.

4 Bk. Gazzâlî, el-Müstasfâ, I, 13 .

5 Bk. Seyyid, Asâletü ilmi'l-kelâm, s. 45.

6 Tefsir ve hadis disiplinlerinin, kelâm tartışmalarından bağımsız bir şekilde, nasları salt hermenötik bir kaygıyla yorumlayabilmesi, bunu sağlayacak bir usul geliştirebilmesi durumunda, kelâmın naslardan istinbat ettiği ön kabulleri belirlemesi 
hakkuk eden durum daha çok bunun aksidir. Önce kelâm ilminde mezheplerin temel kabulleri belirlenmekte, ardından naslar bu kabuller çerçevesinde yorumlanmaktadır. Bu kabullerin belirleniş sürecinde dış etkilerden bağımsız bir tefsir faaliyetinin yapıldığını söylemek de zordur. Meselâ, yukarıda Râzî̉en aktardığımız üzere, hangi âyetin muhkem, hangisinin müteşâbih kabul edileceğinin belirlenmesi, tefsir disiplininin iç gereklerinden yani nesnel anlama ulaşmaya ilişkin kriterlerden değil, kelâmî tartışmalara özgü kaygılardan yani mezhebî kabullerden hareketle yapılmıştır. Kelâm ilminin bu belirleyiciliğinin ötesinde, müfessirlerin kendilerine özgü bir tefsir anlayışına ya da kelâmî kabullerden bağımsız bir Kur'an tasavvuruna sahip olup olmadıklarının araştırılması büyük önem arzetmektedir. Diğer bir ifadeyle, müfessirin tefsir faaliyetinde esas alacağ i ilkeleri belirleyen özgün bir tefsir usulünün bulunup bulunmadığı tartışmalıdır.

Klasik tefsir usulünde hangi âyetin muhkem, hangisinin müteşâbih sayılacağı, tefsirde esbâb-1 nüzûlün ne ölçüde ve hangi şartlar altında belirleyici kabul edileceği ya da dil bilimi açısından birden fazla ve hatta birbirine zit anlamlara gelmesi mümkün olan lafızların bu anlamlardan hangisine ve hangi gerekçeyle hamledileceği gibi birçok önemli husus, fikıh usulünde, ağırlıklı olarak literal yoruma meyyal kaideler çerçevesinde ele alınmıştır. Benzer şekilde Kur'an karşısında müfessirin, yazılı metni anlama çabası gösteren bir yorumcu gibi mi, yoksa canlı/şifahî bir konuşmaya tanık olan ve konuşmanın ardındaki esas gündemi anlamaya çalışan bir dinleyici gibi mi hareket edeceği noktasında temel bir Kur’an tasavvuru geliştirmek adına ilk seçeneğe ağırlık verilmiş, böylelikle çoğu zaman Kur’an’n yazılı belge gibi okunması metodolojik bir yöntem olarak benimsenmiş görünmektedir.

büyük oranda mümkündür. Meselâ rü’yetullah meselesinde nasların, şu ya da bu kelâmî paradigmadan bağımsız olarak yorumlanması durumunda elde edilecek veri, kelâmcının “tanrı anlayışı”nı önemli ölçüde belirleyebilir. Diğer bir ifadeyle, tefsir ve hadisin, kelâmın kullanacağı verileri, kelâm tartışmalarını önceleyen bir perspektif üzerinden oluşturabilmesi, kelâmın kullanacağı önemli bazı verilerin kelâm dışından belirlenmiş olması anlamına gelecektir. Hâlihazırda kelâmcının önceden sahip olduğu "tanrı tasavvuru" üzerinden nasları yorumluyor veya yorumlayabiliyor olması, başka pek çok etkenin yanı sıra, tefsir ve hadis disiplinlerinin hesabı verilmiş birer yorum metodolojisi geliştirememiş olmalarından kaynaklanıyor görünmektedir. Nitekim hangi âyetlerin muhkem, hangilerinin müteşâbih kabul edileceği dahi tefsir usulünde yeterince tartışılmamış, bu konuda genel geçer tasniflerin ötesinde incelikli ayırımlar yapılmamış olduğundan, kelâmcı tabii olarak kendi mezhebinin ana ilkelerine zâhiren uyan nasları muhkem, diğer nasları müteşâbih kategorisine yerleştirebilmektedir. 
Klasik tanımlamada Kur'an’’n "mushafın iki kapağı arasında bulunan bir

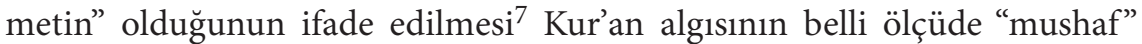
merkezli olduğu intibaını vermektedir. Gerçi klasik Kur’an tanımlarında onun "Hz. Peygamber'e inzal edilen vahiy" olduğu da söylenmiştir; ancak mushaf vurgusunun öne çıkması Kur'an’n canlı bir ortamda inzal edilmesinden kaynaklanan diyalojik yönünün en azından tanım ve tasavvur düzeyinde ikinci plana düşmesine sebebiyet vermiş görünmektedir. Böyle bir durum ise netice itibariyle Kur'an’ı yazılı bir metin şeklinde değerlendirilip mushaf olarak (salt dilsel bir metin olarak) okunmasına ve nüzûl şartları içerisindeki orijinal anlamını belirleyecek en önemli unsur olan sünnet/sîret çerçevesinden bağımsızlaştırılmasına, ${ }^{8}$ ayrıca lafızların dil bilimi açısından muhtemil bulunduğu bütün anlam ihtimallerinin metnin anlam alanına dahil edilmesine sebep olabilmektedir. Klasik tefsirde aynı âyetle ilgili birbirine taban tabana zit yorumların ardarda zikredilmesi ve böylece âyetin bütün bu anlam ihtimallerine açık olduğunun îmâ edilmesi bu tespitimizi desteklemektedir." İbn Âşûr bunu, "Kur'an cümlelerinin taşıyabileceği muhtemel anlamlar, o cümlelerden kastedilen anlam olarak değerlendirilir" (أن المعاني şeklinde ifade etmektedir. ${ }^{10}$ Bununla beraber klasik tefsirin metin (mushaf) merkezli temayülün yanı sıra, Kur'an’ı nüzûl dünyasında ve diyalojik ortamında anlamaya çalışan bir temayülü de ihtiva ettiği açıktır. Bu yazıda konuyu örneklendirmek üzere merkezî bir yer vereceğimiz Enbiyâ sûresinin 23. âyetinin tefsirinde de bu iki temayülün eşgüdümlü bir mevcudiyet arzettiğini görmekteyiz. Ancak biz burada bu temayüllerden ikincisini tercih edecek ve incelediğimiz âyetin bu çerçevede yorumunu yapmaya çalışacağız.

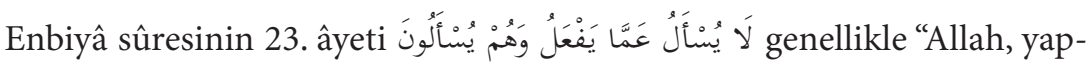
tıklarından sorulmaz, ama kullar sorulurlar" şeklinde anlaşılmakta ve kelâm ilminde ilâhî fiillerin bir illete mebni olup olmadığına ilişkin tartışma çerçevesinde ele alınmaktadır. Hatta bu âyet yer yer, katı cebrî yaklaşım karşısında

7 Bk. Gazzâlî, el-Müstasfâ, II, 9-10; Serahsî, el-Muharrer, I, 210; İbn Haldûn, Mukaddime, S. 405.

8 Fıkıh usulünde sünnet temel bir teşrî kaynağı olarak kabul edilmiş olmakla beraber, sünneti nakleden rivayetler de salt birer metin olarak ele alınmaktadır. Bu konuda önemli bir eleştiri için bk. Görmez, Sünnet ve Hadisin Anlaşılmasında Metodoloji Sorunu, s. $163 \mathrm{vd}$.

9 Meselâ Mâtürîdînin sıklıkla kullandığı, "Bu âyetin şu anlama gelme ihtimali de vardır" şeklindeki ifadeleri, yukarıdaki değerlendirmemize imkân tanıyacak işaretler içerir. Râzî, Kurtubî, Âlûsî gibi pek çok müfessirin yöntemleri de, yorumlar arasında tercihte bulundukları, eleştiri ve analiz yaptıkları yerler istisna sayılırsa, buna yakındır.

İbn Âşûr, et-Tahrîr, I, 93. 
akla gelen itirazların bertaraf edilmesi için ${ }^{11}$ bir argüman olarak da devreye sokulmaktadır. ${ }^{12}$ Fiillerinden dolayı Allah’̉ hesaba çekmenin ya da O’na bu amaçla soru yöneltmenin itikadî açıdan imkânsız görülmesi, bütün mezheplerin ittifak ettiği bir husus olmakla beraber, ${ }^{13}$ Mu'tezile'ye göre bu durumun sebebi Allah’in bütün fiillerinin güzel ve O’nun çirkin şeyleri yapmaktan münezzeh olması, Eşarâiler'e göre ise ilâhî fiillerin ardında herhangi bir amaç (illet/garaz) bulunmamasıdır. Mu'tezile’nin bu konudaki görüşü (ilâhî fiilleri tâlil etme düşüncesi) Eş́arîler dışında hemen bütün mezheplerce, Allah’a zorunluluk atfetme konusundaki itiraz kaydı haricinde, kabul görmüştür. ${ }^{14}$ İbn Kayyim el-Cevziyye (ö. 751/1350) Şifâül-alîl adlı risâlesinde konuyu genişçe ele alıp ilâhî fiillerin illetsiz olduğunu savunanlara cevap vermiş ve "Ehl-i İslâm’n cumhurunun, nazar ehlinin ve fukahanın” görüşünün, tâlili kabul etme istikametinde olduğunu ifade etmiştir. ${ }^{15}$

Meselenin bu yazıda ele alınacak yönü, müşriklere hitap ettiği hem nüzûl döneminden hem de metin içi siyakından belli olan bir âyette, ilâhî fiillerin illeti meselesinin konu edilmesinin mümkün olup olmadığıdır. Çünkü "lâ yüs'elü ammâ yef'al" ifadesiyle, "Allah’’n fiilleri illetsizdir, dolayısıyla O’nun fiilleri hakkında 'Niçin böyle yaptı?' gibi sorular soramazsınız!” şeklinde bir anlamın kastedilmiş olabilmesi için, muhatapların birtakım ilâhî fiilleri anlamsız bulup çeşitli itirazlar seslendirmiş yahut başka saiklerle Allahı̉n fiillerinin ardında illet aramış olmaları icap etmektedir. "Allah'ın fiilleri illetsizdir, dolayısıyla O’nun fiilleri hakkında 'niçin böyle yaptı?' gibi sorular soramazsınız!" cümlesi, ancak bu tür itirazların seslendirildiği bir ortamda anlamlı bir karşılık sayılabilir. Oysa âyetin nüzûl ortamındaki muhatapları olan müşrikler, Allah’ı sorguya çekebilme düşüncesini ihtiva edebilecek bir inanca sahip değildiler. Onların Allah tasavvurları Allah’ın kudretinde, ilminde ya da diğer herhangi bir vasfında eksiklik olduğunu içermemekte-

11

\footnotetext{
Bk. Nizâmeddin en-Nîsâbûrî, Garâibü'l-Kur'an, V, 15; Derveze, et-Tefsîrü'l-hadîs, V, 263.

Meselâ İbn Hazm gerek el-Muhallâ'da gerek el-İhkâm'da bu âyeti bolca kullanmaktadır. Bu kullanımların genelinde, muhatabın muhtemel itirazlarına cevap verme arzusu söz konusudur. Bk. İbn Hazm, el-Muhallâ, I, 38, 163; IV, 178; V, 38; VI, 266; VII, 93, 319, 478; VIII, 70, 116; IX, 456; X, 192; el-İhkâm, I, 85, 115; III, 105, 144; IV, 74; VII, 15, 61; VIII, 85, 102, 103, 104, 117, 125. Bu referanslara bakıldığında, İbn Hazm’ın bu âyeti kullanımının çoğunlukla konuyla ilgisiz olduğu görülecektir.

Bk. Fahreddin er-Râzî, Mefâtîhu'l-gayb, XXII, 156.

Bk. Âlûsî, R̂̂uhu'l-meânî, XVII, 29. Âlûsî yukarıdaki tespiti yapmış ve Mâtürîdî mezhebinin görüşünün, Şerhu'l-Makāsıd'da ifade edildiği üzere tâlil istikametinde olduğunu belirtmiş olmakla beraber, Teftâzânînin söz konusu eserde ilâhî fiillerin genel anlamda tâlil edilemezliğini savunduğunu, ancak şer î hükümleri bundan istisna ettiğini görmekteyiz. Bk. Teftâzânî, Şerhu'l-Makāsıd, IV, 301-3.

Bk. İbn Kayyim el-Cevziyye, Şifâül-alîl, II, 122-25.
} 
dir. Kur'an açısından onların tasavvurundaki sorun, O’na ortak koşmalarıdır. O’na ortak koşmak ise, ilk bakışta akla gelebilecek olanın aksine, başka varlıkların gerçekten Allah'la aynı kudrete sahip olduklarını ve bu itibarla Allah’a ortak olduklarını düşünmek, bu çerçevede bir çoktanrıcı anlayışa inanmak değil, ${ }^{16}$ bizzat Kur'an’n ifade ettiği üzere, ${ }^{17}$ bazı varlıkları Allah nezdinde değerli telakki edip onların yardımını ummak ve bu sebeple onlara ibadet derecesinde tâzim göstermektir. Dolayısıyla müşriklerin "Acaba Allah şu fiili niçin yaptı?” şeklinde bir teolojik tartışmaya girmiş olduklarını yahut Allah’a karşı itiraz anlamına gelebilecek bir temerrüt tavrı içinde olduklarını düşünmek, vâkıaya uygun olmayacaktır. Bu durumda, âyetin ilâhî fiillerin illeti meselesiyle tek ilgisi, lafız benzerliğinden ibaret görünmektedir. İlk dönem tefsirlerinde işaret edildiği ve İbn Âşûr'un (ö. 1973) detaylıca üzerinde durduğu üzere, ${ }^{18}$ âyetin nüzûl dönemindeki muhtevası, meleklerin Allah’n kızları olduğuna, dolayısıyla ilâhî bir nitelik taşıdıklarına inanan ve onlara ibadet eden müşriklere cevap mahiyetindedir. Buna göre âyet, "Melekler yaratılmış ve âhirette hesaba çekilecek iken onlara nasıl kulluk edersiniz; kulluk edilmeye lâyık yegâne ilâh, hesaba çekilemeyecek olan mutlak kudret sahibi Allah'tır" mesajını iletmektedir.

$\mathrm{Bu}$ yazıda tercih edilecek görüş en genel hatlarıly bu istikamette olup Kur'an âyetlerini nüzûl şartları içerisinde anlamayı esas almakta ${ }^{19}$ ve sonraki

16 Bk. Fahreddin er-Râzî, Mefâtîhu'l-gayb, II, 122.

17 Nitekim Kur’an, müşriklerin, putların kendilerini Allah’a yakınlaştıracaklarına inandıklarını ve bu yüzden onlara taptıklarını ifade etmektedir (bk. ez-Zümer 39/3). Yine onların Allah’ın yaratıcılığını ve kudretini kabul ettikleri de birçok âyette açıkça ifade edilmiştir (bk. el-Ankebût 29/61, 63; Lokmân 31/25; ez-Zümer 39/38; ez-Zuhruf 43/9, 87).

18 Bk. İbn Âşûr, et-Tahrîr, XVII, 45-46.

19 Nüzûl şartlarını belirlemenin zorluğu, metnin anlamının orada öylece duran bir "huzur" (presence) arzetmediği ve nüzûl şartlarının tespitine yönelik her çabanın yorumcunun içinde bulunduğu tarihsel-kültürel koşullarla belirlenmiş olacağ açıktır. Gadamer, herhangi bir tarihî döneme ait verilerin değerlendirilmesinin, bu değerlendirmeyi yapan yorumcudan bağımsız olamayacağını, her yorumun ancak okuyucunun "etkin tarihi” eşliğinde mümkün olduğunu yeterli açıklıkla göstermiştir. Dahası Heidegger, insan aklının her türlü faaliyetinin, zaten önceden içerisinde konuşlanmış, yetişmiş ve "o ana kadar" yaşamış olduğu ortam tarafından belirlenmiş olduğunu, dolayısıyla her türlü etkiden bağımsız (salt/pure) bir akıldan bahsetmenin mümkün olmadığını, böylesi bir (Kartezyen) salt akıldan söz etmenin metafiziksel bir kabulden ibaret olduğunu göstermiştir. Bk. Sheehan, "Dasein”, s. 193-213; Heidegger, Varlık ve Zaman, s. 40 vd. Ancak Heidegger-Gadamer çizgisinin, her türlü objektif değerlendirmeyi yadsıyan Derridacı dekonstrüksiyon stratejilerine dönüştügü postmodern yaklaşımların sağduyuya yakın olmadığı da açıtır. Yorumcu her ne kadar kendi "şartları" tarafından belirlenmiş olsa da, insan aklı bir şekilde kendi şartlarını aşabilme ve başkasını anlayabilme, bir başka tarihsel-kültürel ortamı kavrayabilme 
asırların paradigmalarıyla yapılan anakronik yorumlara işaret etmeyi hedeflemektedir. Burada ilgili âyet çerçevesinde, tefsir literatüründe yer alan fikirler klasik ve çağdaş birçok tefsir eserinden takip edilecek olmakla beraber özellikle Fahreddin er-Râzî, Âlûsî (ö. 1127/1715) ve İbn Âşûr gibi, konuyu daha teferruatlı bir şekilde ele alan müfessirlerin yorumlarına ağırlık verilecektir. Müfessirlerin değerlendirmeleri özet olarak verildikten sonra âyetin metin içi bağlamı (siyak ve sibak) ve nüzûl şartları incelenecek, bu çerçevede "lâ yüs'elü ammâ yef'alü ve hüm yüs'elûn" cümlesinin ilk muhataplar nezdinde nasıl bir anlama tekabül ettiği (etmiş olabileceği) tespit edilmeye çalışılacak, tefsirde kelâm tartışmalarının etkisi bu âyet örneğinden hareketle değerlendirilecek ve tefsir disiplininin aslî görevinin, yer yer ifade edildiği üzere, kelâm ve fikıh ilimlerine veri sağlamak değil, Kur'an âyetlerinin nüzûl çağında ne anlama geldiklerini tespit etmeye çalışmak olduğu şeklindeki yaklaşım savunulacaktır.

\section{Enbiyâ Sûresinin 23. Âyetinin Tefsirlerdeki Yorumu}

Erken dönem müfessirlerinden Mukātil b. Süleyman (ö. 150/767) bu âyetin tefsirinde Allah'in melekleri hesaba çekeceğini ifade etmekte, konuyu bu çerçevede değerlendirmektedir ki onun bu yorumu, ileride göreceğimiz üzere, İbn Âşûr tarafından tafsilâtlı olarak izah edilmiştir. Mukātil'e göre "ve hüm yüs'elûn" (onlar sorulur) ifadesiyle kastedilen, kıyamette meleklere, "Sizler mi bu kullarımı saptırdınız, yoksa onlar mı yoldan saptılar?"20 ve "Yoksa bunlar sizlere mi ibadet ediyorlardı?"21 âyetlerinde ifade edildiği şekliyle sorulacak olan sorulardır. ${ }^{22}$ Taberî (ö. 310/922), "ve hüm yüs'elûn" ifadesinin "hesaba çekilmek"le ilgili gönderimine işaret etmekte, fakat âyetin başındaki "lâ yüs'elü ammâ yef'al" ifadesini, Katâde (ö. 117/735), İbn Cüreyc (ö. 150/767) ve Dahhâk’ten (ö. 105/723) üç ayrı rivayete dayandırarak; "Allah’a, hayat, ölüm, izzet verme, zillete düşürme gibi fiilleri konusunda soru soracak kimse yoktur ... kendisine herhangi bir fiili konusunda bunu niçin yaptın ya da niçin yapmadın diye soracak kimse yoktur" şeklinde tefsir etmektedir. ${ }^{23}$ Tâbiîn rivayetlerinde ve Taberînnin yorumunda ilâhî fiille-

imkânına da sahiptir. Gadamer'in “ufukların kaynaşması” tabiriyle kastettiği şey buna yakındır. Dolayısıyla Kur'an yorumcusunun nüzûl çağına dair, kendi dünyasının verilerinden kısmen bağımsız bir tasavvur geliştirebilmesi ve Kur'an'ı, sahâbe neslinin anladığına mümkün mertebe yakın bir tarzda anlamayı başarabilmesi, en azından teorik olarak mümkündür. el-Furkān 25/17.

21 Sebe' 34/40.

22 Mukātil b. Süleyman, Tefsîru Mukātil b. Süleymân, II, 355.

23 Bk. Taberî, Câmiu'l-beyân, XVI, 247. 
rin bir illete mebni olup olmadığı meselesine henüz girilmemiş olması ve

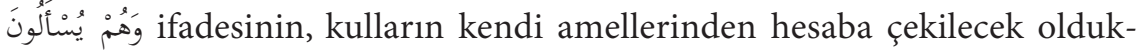
ları şeklinde anlaşılması dikkate değerdir. İleride görüleceği üzere bu ifadenin tefsirindeki merkezî nokta, sonraki asırlardaki kelâm tartışmalarıyla birlikte, konunun âhiretle ilgili yönünden ziyade, fiillerin illeti meselesine dönüşecektir. Taberî ile birlikte başlamış görünen bu dönüşüm sürecinin onunla yaklaşık aynı asırda yaşamış olan Mâtürîdînin (ö. 333/944) ifadelerinde görülmesi mümkündür. Mâtürîdî, ilgili ifadenin muhtemel üç anlamını vermekte, fakat birbirine kısmen yakın olan bu anlamlar arasında herhangi bir tercih yapmamaktadır. Ona göre âyetin muhtemel ilk anlamı, "Allah bütün fiillerini kendi mülkünde ve saltanatında yaptığ için kendisine bunlar sorulmaz. Çünkü sadece başkasının mülk ve saltanatında bir fiil işleyen kimseye o fiil ile ilgili soru sorulur" şeklindedir. Bu anlam ihtimali çerçevesinde âyet, sahibinin emir ya da izni olmaksızın hiçbir şey üzerinde tasarrufta bulunmanın câiz olmadığına delâlet etmektedir. Bundan dolayı, "Eşyada asıl olan ibâhadır, başkasının mülkünde tasarruf, mutlak anlamda câizdir” görüşünü savunanların iddiaları geçersizdir. ${ }^{24}$ Mâtürîdînin verdiği bu ilk yorum Eş̧arîler'e ait olmalıdır. İlerleyen dönemlerde Eş'arî âlimlerin eserlerinde, "Kendi mülkünde tasarrufta bulunan kimse, bu tasarrufundan mesul olmaz" şeklindeki argümanı görmek mümkündür. ${ }^{25}$ Haddizatında Eş́arî kelâmının, Tanrı-insan ve Tanrı-âlem ilişkilerine taalluk eden bahisler (irade, tâlil, sebeplilik vb.) söz konusu olduğunda en hassas olduğu noktalardan biri "hudûs" fikri ise, bir diğeri de "kādir-i muhtar" tanrı anlayışının muhafazasıdır. Bununla beraber kādir-i muhtar tanrı düşüncesinin sadece Eş'arîler’e mahsus olmadığı, filozoflar karşısında bütün kelâmcıların ortak refleksi olduğu da unutulmamalıdır. ${ }^{26}$ Dolayısıyla tâlil meselesindeki Eşsarî yaklaşım ile kādir-i muhtar tanrı düşüncesi arasında bir lâzım-melzum ilişkisi bulunmamaktadır. Mâtürîdînin kendi görüşü, muhtemelen ikinci sırada verdiği görüştür. Buna göre Allah’n yaptığından sorulmaz oluşunun sebebi, O’nun zatı itibariyle hikmet sahibi olmasıdır. Bu yüzden O’nun fiilleri hikmet dairesinin dişına çıkmaz. Dolayısıyla ancak fiillerinde bir anlamsızlık/ hikmetsizlik ve abeslik (sefeh) bulunması muhtemel kimselere, "Bunu niçin yaptın?" gibi bir soru sorulabilir; fiillerinin hikmet dairesi dışına çıkması muhtemel olmayan zata değil. ${ }^{27}$ İlerleyen dönemlerde Mâtürîdî mezhebine

24 Mâtürîdî, Te’vîlâtü'l-Kur'ân, IX, 270.

25 Meselâ bk. Gazzâlî, el-İktisâd, s. 183; Şehristânî, Nihâyetü'l-ikdâm, s. 410-11.

26 Bk. Türker, "Mukaddime'de Aklî İlimler Algısı”, s. 4.

27 Mâtürîdî, Te’vîlâtü’l-Kur'ân, IX, 270. 
mensup âlimlerin eserlerinde bu argümanı görmek mümkündür. ${ }^{28} \mathrm{Bu}$ görüş Mu'tezile’nin görüşüyle paralellik arzediyor olsa da, hem meseleyi hüsün-kubuh konusuna çekmemesi hem de ilâhî fiilleri "zorunluluk/vücûb" kavramıla ilişkilendirmemesi sebebiyle, Mâtürîdî mezhebinin tutumunu yansitmaktadır. Üçüncü yorum olarak Mâtürîdî, kulun Allah’a emir kipiyle hitap etmesinin ancak dua anlamında mümkün olabileceğini, kendisinden daha üst makamdakine emir kipiyle konuşan kimsenin bu emir kipiyle ancak bir ihtiyacını ifade etmek isteyebileceğini söylemektedir. ${ }^{29}$

Mâverdî (ö. 450/1058) bu âyetle ilgili dört görüşe yer vermektedir. İbn Cüreyc'den naklettiği ilk görüşe göre âyet kulların Allah’ın fiillerini sorgulayamayacaklarını, Allah’ı ise onları sorgulayacağını söylemektedir. İkinci görüşte bunun sebebi açıklanmaktadır; buna göre ilâhî fiillerin mahzâ doğru ve hikmetli olmasına karşılık kulların fiillerinin yanlış olma ihtimali vardır, bu yüzden de ilâhî fiiller sorgulanamaz. Üçüncü görüşe göre âyetin anlamı, "Allah fiillerinden hesaba çekilemez, kullar ise hesaba çekilirler" şeklindedir. Dördüncü görüş Mâverdînnin kendisine aittir, buna göre anlam, "Allah fiillerinden sorgulanamaz (muâhaze edilemez), kullar ise sorgulanırlar" şeklindedir..$^{30}$ Burada sadece İbn Cüreyc'den nakledilen ilk görüş, ilâhî fiillerin illetsizliği tartışmalarına kapı açacak türden gözükmektedir. Dikkat edileceği üzere diğer üç görüşün ortak noktası, filllerin sebebinin ya da illetinin bulunup bulunmaması ya da sorulması değil, bu fiillerden hesaba çekilme konusudur. ${ }^{31}$ Buradaki hesaba çekilme ifadesi, âhirete ilişkin gönderimi dikkate alındığı ve bu husus, sorgulanacak kullardan maksadın melekler olduğuna dair Mukātil'in ifadeleriyle birlikte düşünüldüğünde, âyetteki vurgunun melekleri Allahı̉n kızları olarak görüp onlara ibadet eden müşriklere cevap şeklinde olduğunu göstermektedir. Mâverdînin aktardığg görüşlerden üçü, bu yoruma imkân tanımaktadır. Buna göre âyet müşriklere, "Bizzat kendileri hesaba çekilecek olan varlıklara ibadet edilmez, ibadete lâyık yegâne kudret, hesaba çekilemeyecek olan Allah’tır" demiş olmaktadır. Bu çerçevenin dışında kalabilecek İbn Cüreyc rivayeti ise Kurtubî tarafından şu önemli kayıtla izah edilmiştir:

28 Pezdevî, Usûlü'd-dîn, s. 134; Beyâzîzâde Ahmed Efendi, İşârâtü’l-merâm, s. 131-32.

29 Mâtürîdî, Te’vîlâtü̉l-Kur'ân, IX, 270.

30 Bk. Mâverdî, en-Nüket, III, 442.

31 Âyetteki "sual" kelimesini "hesaba çekmek" olarak anlayınca, konunun ilâhî fiillerin illetleriyle ilgisi kalmamakta, müşriklerin melekleri Allah’a ortak koşmalarına cevap mahiyetinde olması ön plana çıkmaktadır. 


$$
\text { بين بهذا أن من يسأل غداعن أعماله كالمسيح والملائكة لايصلح للإلهية. }
$$

Böylece (İbn Cüreyc) şu hususu beyan etmiş olmaktadır ki mesih ve melekler gibi yarın (âhirette) amellerinden hesaba çekilecek olan varlıklar ilâhlık vasfını haiz olamazlar. ${ }^{32}$

Görüldüğg̈ gibi Kurtubînin izahları çerçevesinde okunduğunda, İbn Cüreyc'in görüşünün de tâlil meselesiyle ilgili olmadığ anlaşılmaktadır. Benzer bir değerlendirme, Celâleyn şârihlerinden Cemel (ö. 1204/1789) ve Sâvî (ö. 1241/1825) tarafından da yapılmıştır. ${ }^{33}$ Kaldı ki âyetin Kaderiyye/ Mu'tezile mezhebine kesin bir cevap olduğunu ifade etmesine ve konuyu tâlil ile ilişkilendirmesine rağmen Kurtubî, İbn Cüreyc'in ifadesini bu şekilde yorumlamıştır. Bu durum, Mâverdîdde yer alan nakillerin hiçbirinin tâlil meselesiyle ilişkilendirilemeyeceğini, dolayısıyla âyetin tefsirinde girişilen kelâm tartışmalarının ilk dönem tefsirlerinde herhangi bir kökeninin bulunmadığını göstermesi açısından önem arzetmektedir. Mâverdî gibi sahâbe ve tâbiîn âlimlerinin görüşlerini derlemesiyle meşhur bir diğer müfessir olan İbnü’lCevzî de (ö. 597/1200), âyetin tefsirinde hiçbir rivayete yer vermemiştir. ${ }^{34}$

Âyetin önemli ölçüde kelâm tartışmalarının merkezine yerleştirildiği tefsir metinlerinden biri, Zemahşerînnin (ö. 538/1143) el-Keşşâf'ıdır. Zemahşerî "lâ yüs'elü ammâ yef'al" ifadesini yorumlarken Allah’ın kudretiyle kralların kudretini mukayese etmekte, kralın kendi tebaası tarafından sorguya çekilememesiyle Allah'a soru sormanın imkânsızlığını mukayese etmekte, buna ilâve olarak ilâhî fiillerin ardındaki hikmet gerekçesine vurgu yapmakta ve insan aklında "ilâhî fiillerde herhangi bir hatanın var olamayacağı" hakikatinin sabit olduğunu ifade etmektedir. ${ }^{35}$ Diğer bir ifadeyle Zemahşerî ilâhî fiillerin sorguya çekilemez oluşunu iki sebebe bağlamaktadır. Bunlardan birincisi, o fiillerin sahibi olan zatın (Allah), fiilleri sorgulanamayan krallardan çok daha yüce olması, bütün mahlûkatın yaratıcısı ve sonsuz kudret sahibi olmasıdır. Bu argüman, ileride göreceğimiz üzere, Mưtezilî olmayan âlimler tarafından da kullanılacaktır. İkincisi ise ilâhî fiillerin muhakkak bir hikmet gerekçesiyle yapılmış olduğuna ve Allah’̉n çirkin fiil işlemesinin câiz olmadığına dair akıllarda mevcut olan sabit hakikattir. Kādî Abdülcebbâr da (ö. 415/1024) Allah’ın fiillerinden dolayı sorguya çekilememesinin sebebini,

32 Bk. Kurtubî, el-Câmi‘, XIV, 190.

33 Bk. Cemel, el-Fütûhâtü'l-ilâhiyye, III, 136; Sâvî, Haşiyetü's-Sâvî, III, 62.

34 Bk. İbnüll-Cevzî, Zâdüll-mesîr, V, 345.

35 Bk. Zemahşerî, el-Keşşâf, IV, 137. 
onun her fiilinin mutlak surette güzel olması ve çirkin işlerin onun için câiz olmaması olduğunu ifade etmiştir. ${ }^{36}$

Buraya kadar verdiğimiz görüşler, tefsir geleneğinde bu âyet çerçevesinde yürütülen tartışmaların başlangıç aşamasını gösterir niteliktedir. Bundan sonraki dönemlerde Fahreddin er-Râzî ve Âlûsî gibi müfessirler konuyu kelâm ilmindeki detaylarıyla tartışmaya başlamışlar ve ilk dönem tefsirlerinde kısmen gözlemlediğimiz, "nüzûl ortamını dikkate alma" hassasiyetini büyük ölçüde terketmişlerdir. Yorumdaki bu değişimi kelâm tartışmalarının tefsir metinleri üzerindeki bâriz etkisi olarak değerlendirmek mümkündür. Bazı tefsir metinlerinde ise âyetin tefsirinin kısmen senkretik sayılabilecek bir tarzda ele alındığını görmekteyiz. Buna örnek olarak Kurtubî̀nin (ö. 671/1272) yorumunu zikredebiliriz. Göreceğimiz üzere Kurtubî hem

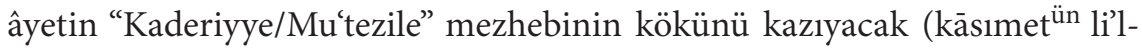
Kaderiyye) bir âyet olduğunu ifade etmekte, hem de İbn Cüreyc'den naklettiği bir rivayet vasitasıyla, âyetin meleklerin ulûhiyyetine dair iddialara cevap olduğunu söylemektedir. Yani birbiriyle taban tabana zıt iki yorumu da benimseyerek vermektedir. Kurtubî metnindeki yorumlar müstakil paragraflar halinde aşağıdaki şekilde gösterilebilir:

1. Bu âyet Kaderiyye (Mútezile) ve (benzer görüşleri savunan) diğer mezheplerin kökünü kazlyacak bir âyettir.

2. İbn Cüreyc şöyle demiştir: "Mahlûkat Allah’a, onlar üzerindeki takdirinden dolayı soru soramaz, Allah ise onları amellerinden sorgular, çünkü onlar kuldurlar." Böylece (İbn Cüreyc) şu hususu beyan etmiş olmaktadır ki Mesih ve melekler gibi yarın (âhirette) amellerinden hesaba çekilecek olan varlıklar ilâhlık vasfını haiz olamazlar.

3. Bir yorum da şöyledir: Allah fiillerinden hesaba çekilmez, kullar ise çekilirler.

4. Rivayete göre bir kişi Hz. Alìye, "Ey müminlerin emîri! Rabbimiz kendisine isyan edilmesini ister mi (sever mi)?" diye sormuş, o da, "Herhangi bir kimsenin Rabbimiz'in rızası olmaksızın O’na isyan etmesi mümkün müdür?" demiştir. Bunun üzerine o kişi, "Peki Allah hidayeti benden alıkoyar ve dalâleti bana verirse, o takdirde bana iyilik mi yapmış olur yoksa kötülük mü?" diye sorar. Hz. Ali de, "Senin hakkın olan bir şeyi senden alıkoysa kötülük etmiş olur, ama sana olan fazlını ve ihsanını alıkoyacak olursa böyle olmaz; zira $\mathrm{O}$, ihsanını dilediğine verir" demiş ve bu âyeti okumuştur.

36 Kādî Abdülcebbâr, Tenzîhü’l-Kurân, s. 26o. 
5. İbn Abbas'ın şöyle dediği rivayet edilmiştir: "Yüce Allah Hz. Mûsây1 peygamber olarak seçip kendisiyle konuştuktan ve Tevrat'ı inzal ettikten sonra Hz. Mûsâ şöyle demiştir: Allahım! Sen azamet sahibi Rab’sin, itaat edilmeyi dilesen herkes sana itaat eder, isyan edilmemeyi dilesen kimse sana isyan edemez. Sen itaat edilmeyi sevmektesin, ama bu halde bile sana isyan edilebilmektedir. Bu nasıl mümkün olmaktadır ey Rabbim!" Allah da ona şöyle vahyetti: Ey Mûsâ! Ben yaptıklarımdan sorulmam, ama onlar sorulurlar!"37

Dikkatle incelendiğinde bu metnin birbiriyle ilgisiz ve zıt görüşlerin, herhangi bir uzlaştırma, mukayese ya da tartışma yapılmadan verildiği "senkretik tefsir” örneği teşkil ettiğini gözlemlemek mümkündür. ${ }^{38}$ Öncelikle ifade edelim ki Kurtubînnin burada Hz. Alìye atfettiği ifade, İbn Hacer el-Askalânî (ö. 852/1448) tarafından, bir Ehl-i sünnet âlimi ile bir Mứtezile âlimi arasında geçen bir tartışmada kullanılan diyalog olarak nakledilmektedir. ${ }^{39}$ Hz. Mûsâ ile ilgili olarak İbn Abbas'tan nakledilen rivayet ise hem senet açısından problemlidir, hem de muhteva olarak uyarlama olduğu bâriz bir şekilde ortadadır. ${ }^{40}$

Metnin başında âyetin Kaderiyye mezhebine ve benzer görüşleri savunanlara yönelik sıkı bir cevap olduğunun söylenmesiyle hemen devamında İbn Cüreyc'den yapılan nakil çelişkilidir. Zira bu naklin devamında geçen "Böylece şu hususu beyan etmiş olmaktadır ki, Mesih ve melekler gibi yarın (âhirette) amellerinden hesaba çekilecek olan varlıklar ilâhlık vasfını haiz olamazlar" ifadesinde, âyetin Kaderiyye mezhebine değil, Mesih'in ve meleklerin ulûhiyyetine inanan müşriklere reddiye olduğu açıktır. Hemen ardından kullanılan, "Bir yorum da şöyledir: Allah fiillerinden hesaba çekilmez, kullar ise çekilirler" ifadesi, âyetteki tevhit vurgusuna işaret eden ilk dö-

37 Kurtubî, el-Câmî̀, XIV, 190 .

38 Senkretizm, Lalandëa göre, değişik kökenli farklı iddiaların birleştirilmesi, bir araya toplanması anlamına gelir. Buna karşılık eklektizm, değişik kökenli tez ve iddiaların bir uyum içerisinde, insicamlı bir şekilde bir araya getirilip derlenmesidir (bk. Lalandé, Vocabularie, III, 1407-8). Görüldügü gibi senkretizm ile eklektizm arasındaki fark, ilkinde belli bir sistem/insicam gözetilmeksizin bir araya getirilen tezlerin, ikincisinde belli bir sistem içerisinde derlenmesidir. Senkretik tefsir ifadesiyle, herhangi bir âyetin tefsirinde, birbiriyle ilgisiz yahut zıt görüşleri ardı ardına sıralayan ve bunlar arasında herhangi bir tercih ya da değerlendirme yapmayan tefsir tarzını kastediyoruz. Bk. İbn Hacer el-Askalânî, Fethu'l-bârî, XIII, 451.

$40 \mathrm{~Hz}$. Mûsâ ile Allah arasında geçtiği ifade edilen diyalog, kelâm kitaplarında Ehl-i sünnet âlimleri ile Mưtezile âlimleri arasında sıkça örneklerine rastlayabileceğimiz diyaloglara benzemektedir. Buna benzer birçok rivayet Süyûtî tarafından da nakledilmiştir. Bk. Süyûtî, ed-Dürrü'l-mensûr, X, 280 vd. Ayrıca senedinde yer alan Ebû Yahyâ el-Kattât, ricâl âlimlerinin çoğunluğu tarafından zayıf bulunmuştur (bu bilgi Kurtubî muhakkiki Abdülmuhsin et-Türkî tarafından nakledilmektedir). 
nem müfessirlerinin yorumlarını andırırken ${ }^{41}$ devamında Hz. Ali’ye ve İbn Abbas'a atfedilerek nakledilen rivayetler, âyeti tamamen Eşariyye-Mu'tezile tartı̧̧ması eksenine yerleştirmeye yöneliktir. Burada Kurtubî, âyeti nüzûl şartları eşliğinde değerlendirme refleksi ile kelâm tartışmaları arasında kararsız görünmektedir.

Şiî tefsir geleneğinde de ilâhî fiillerin illetliliği meselesindeki görüşler, tıpkı Mu'tezile'de oluğu gibi, hikmet ve isabetlilik kavramlarıyla gerekçelendirilmiştir. Kummî (ö. 307/919) âyetin Seneviyye’ye reddiye anlamına geldiğini ifade ederken, ${ }^{42}$ Tûsî (ö. 460/1067) ve Tabersî (ö. 548/1153) gibi müfessirler ilâhî fiillerin hesaba çekilmezliğinin temel gerekçesi olarak hikmet unsurunu özellikle zikretmişlerdir. ${ }^{43}$ Yine Tabersî, temriz sîgası olarak kabul edilen "kīle=derler ki" ifadesiyle de olsa, iki önemli yoruma daha yer vermektedir. Bunlardan birincisine göre âyet Allah’ın rubûbiyyet iddiası sebebiyle mesul olmadığını, buna karşılık başka varlıkların bu iddiada bulundukları takdirde mesul olacakları anlamına gelir. Tabersî bu görüşü temriz sîgasıyla vermiş olsa da, âyetin siyakının ve nazmının bu anlama delâlet ettiğini ifade etmektedir. Bu da onun temriz sîgasıyla verdiği görüşleri benimsemediği şeklinde bir kanaate varmanın yanlış olacağını göstermektedir. Tabersînnin verdiği ikinci önemli görüşe göre âyetin anlamı şöyledir: "Melekler ve mesih Allah’n fiillerini hesaba çekemezken, Allah onları hesaba çeker. Eğer onlar ilâh olsalardı, fiillerinden hesaba çekilmezlerdi". ${ }^{44}$ Nâsır Mekârim Şîrâzî başkanlığında bir grup Şiî müfessir tarafından telif edilen el-Emsel tefsirinde âyetteki "sual" kelimesi tafsilâtlı olarak ele alınmakta ve Allah’n fiilleri hakkında bilgi ve izah isteme anlamında soru sormanın mümkün ve câiz olduğu, buna karşıllk isyan ve itiraz anlamında soru sormanın söz konusu olamayacağ 1 belirtilmektedir. Yine bu tefsirde, Muhammed el-Bâkır'dan (ö. 114/733) nakledilen bir rivayet aracılığıyla, Allah’n filleri hakkında soru sorulamamasının ardında, ilâhî fiillerin tamamının hikmet ve doğruluk niteliklerine sahip olmasının yer aldığ ifade edilmektedir. ${ }^{45}$

Konunun bütünüyle kelâm tartışmalarına dönüştüğü Râzî ve Âlûsî tefsirlerinde, mesele oldukça uzun anlatılmıştır. Râzî konuya başlarken âyetin metin içindeki bütünlüğüne dikkat çekmekte ve öncesiyle irtibatını

41 Sual kelimesi "hesaba çekmek" şeklinde anlaşıldığında âyetin tâlil meselesiyle ilişkisi çok zayıflamaktadır. Çünkü "Allah hesaba çekilemez" önermesi ile "Allah’n fiilleri illetsizdir" önermesi, birbirinden açıç̧a ayrıştırılabilecek iki farklı hususa işaret etmektedir.

42 Bk. Kummî, Tefsîrü̉l-Kummî, II, 69.

43 Bk. Tûsî, et-Tibyân, VII, 239; Tabersî, Mecmau'l-beyân, VII, 59.

44 Tabersî, Mecmau'l-beyân, VII, 59.

45 Bk. Şîrâzî̀, el-Emsel, X, 132-33. 
kurma sadedinde, bütün şirk inançların temelinde ilâhî fiillerin sebeplerini merak edip soruşturma (talebü'l-limmiyye) davranışının bulunduğunu ifade etmektedir. Müşrik olan Mecûsîler, âlemde hem iyilik hem kötülük olduğu ve iyiliğin fâilinin iyi, kötülüğün fâilinin ise kötü olması gerektiği öncüllerinden yola çıkarak, biri iyilikleri diğeri de kötülükleri yaratan iki farklı ilâhın var olması gerektiği sonucuna varmışlardır. Böyle olduğu için de, ilâhî kelâmın mükemmel nazmının bir gereği olarak, bir önceki âyette şirkin yanlışlığına ve tutarsızlığına vurgu yapılmış ve onu takip eden 23. âyette de şirkin sebebi olan (müşriklere cevap sadedinde aslî nükte olan) hususa yer verilmiş, yani ilâhî fiillerin illetsizliği ilkesi vazedilmiştir. ${ }^{46}$

Görüleceği üzere Fahreddin er-Râzî, konunun öncesiyle irtibatı konusunda ilk dönem müfessirlerinin söz ettikleri hususu tamamen görmezden gelmiştir. Hatırlanacağı üzere Mukātil ve Taberînin yorumlarında âyet, müşriklerin melekleri Allah’a ortak koşmalarına cevap sadedindedir ve onlara, "Âhirette hesaba çekilecek varlıkları nasıl Allah’a ortak koşarsınız?" mesajını iletmektedir. Fakat Fahreddin er-Râzî, müşriklerin (kendi örneğine göre Mecûsîler' in) ilâhî fiillerin ardındaki sebepleri fazlaca araştırmaları ve niçin, neden gibi soruları sormaları (talebü'l-limmiyye) neticesinde şirke düşmüş olduklarını iddia etmektedir. Bu iddia birçok açıdan tartışmaya açıktır. Öncelikle Fahreddin er-Râzînin kendisi, Bakara sûresinin 22. âyetinin tefsirinde, şirk inançlarının nasıl ortaya çıktığı meselesine dair hususi bir fasıl açmış ve orada, âlemde hayır ve şer ilâhı olarak iki farklı ilâh kabul eden Seneviyye'yi diğer müşrik gruplardan ayırmış, bunların dışında kalan müşriklerden hiçbirinin varlık, kudret, ilim ve hikmet itibariyle herhangi bir varlığın Allah’a ortak olduğunu iddia etmediklerini, ${ }^{47}$ aksine bazı varlıkları Allah’a yakınlaşmak üzere aracı kıldıklarını ya da teşbih, tâzim, şefaat talebi vb. sebeplerle şirke düştüklerini ifade etmiştir. ${ }^{48}$ Dolayısıyla Fahreddin er-Râzînin şirk inançlarını burada "neden, niçin" gibi sorulara bağlaması ve müşriklerin inançlarını izah sadedinde sadece Mecûsîler'den söz etmesi, kendi söyledikleriyle çelişmektedir. Zira Bakara sûresinin 22. âyetinin tefsirinde, Mecûsîler'in diğer müşriklerden farklı olarak, eşit ilâhî kudrete sahip iki ilâha inandıklarını sarâhaten ifade etmiştir. Bu durumda Mecûsîler diğer müşrik gruplar içinde bir istisna olmakta ve genel anlamda bütün müşrikleri temsil etmemektedirler. Diğer taraftan Mekke müşriklerinin yaratma, rızık verme vesair ilâhî fiiller konusunda Allah'a ortak koşmadıkları, Allah dışında herhangi bir varlığa ilâhî kudret atfetmedikleri, buna karşılık kendilerini Allah’a yakınlaştırması ümidiyle bazı

46 Fahreddin er-Râzî, Mefâtîhu'l-gayb, XXII, 155.

47 Bk. Fahreddin er-Râzî, Mefâtîhu'l-gayb, II, 122.

48 Bk. Fahreddin er-Râzî, Mefâtîhu'l-gayb, II, 123-24. 
varlıkları aracı telakki edip onlara aşırı derecede tâzimde bulundukları bizzat Kur'an tarafından ortaya konulduğu gibi, tefsir, siyer ve Câhiliye dönemine dair mâlûmat veren kaynaklarda da zikredilmektedir. ${ }^{49}$

Bunun ardından Fahreddin er-Râzî, Eşarâiler'in ilâhî fiillerin illetsizliği konusunda ortaya koydukları delilleri özetlemektedir. Bu delilleri aktarmadan önce, Fahreddin er-Râzînin meramının daha iyi anlaşılması için, illetin tanımı konusunda birkaç hususa işaret etmek yararlı olacaktır.

Usulcülere göre illet, şer î bir hükmü gösteren yahut gerekli kılan vasıftır. ${ }^{50}$ Ancak ilâhî hükmü icap ettiren dış bir etkenin varlığını kabul etme anlamında "illet" kavramı, beraberinde bazı tartışmaları da getirmektedir. Ebü’lHasan el-Kerhî (ö. 340/951) illetin mûcip (hükmü gerektirici) olduğunu, hikmetin ise mûcip olmadığını ifade etmiştir. ${ }^{51}$ İlletin bu şekilde tanımlanması, Hanefîler ile Mu'tezile'nin ortak noktası gibi görünse de, aslında Hanefîler'in söz ettiği vücûb, meselenin kullar için olan yönüyle ilgilidir. Ebü'l-Yüsr Fahrülislâm el-Pezdevî (ö. 482/1089) şer î illetlerin bizâtihi mûcip olmadıklarını, asıl mûcip olanın Allah olduğunu, fakat Allah’n hükümleri icap ettirmesinin bizim için gaybî bir nitelik arzetmesi sebebiyle vucûbun illetlere nispet edildiğini, böylece illetlerin kullar açısından hükümleri icap ettiren vasıflar olduğunu, Allah açısından ise sadece alâmet olduğunu ifade etmek suretiyle konuya açıklık getirmiştir. ${ }^{52}$ Buna karşılık Şâfiî usulcüler genel anlamda şer î hükümlerin illetlendirilmesini kabul etmemişler; tahâret, necâset, kölelik, hürriyet gibi vasıfların ve hükümlerin Allah tarafından taabbüdî olarak belirlenmiş hükümler kategorisine girdiğini ve bunların hakikatlerine erme hususunda insanın zayıf, aklının yetersiz olduğunu iddia etmişler, bu tür konulardaki ilâhî hükümlerde illet veya maslahat aramanın beyhude olduğunu, çünkü Allah’n insana güç yetiremeyeceği sorumlulukları dahi yükleyebileceğini (teklîf-i mâ lâ yutâk) savunmuşlar ve Enbiyâ sûresinin 23. âyeti başta olmak üzere birçok âyeti bu hususta delil olarak kullanmışlardır. ${ }^{53}$

Eşarâiler Allah’in fiillerinin herhangi bir şekilde bir illete yani o fiilleri gerektirecek bir sebebe bağlanamayacağını, zira böyle bir durumda Allah’n kudretinde eksiklik olduğu ve O’nun bu eksikliği gidermek için başka şeylere

49 Meselâ Taberînin tâbiîn âlimlerinden Mücâhid'den naklettiğine göre "Lât", vaktiyle Kâbe'de yaşayan ve hacılar için yemekler hazırlayıp onlara ikram eden bir zattır ve öldügü zaman insanlar onun kabrini tâzim etmeye başlamış, böylece onu putlaştırmışlardır. Bk. Taberî, Câmiu’l-beyân, XXII, 47-48.

51 Bk. Kerhî, Usûl, s. 375 .

52 Bk. Şelebî, Ta 'lîlüll-ahkâm, s. 113-14.

53 Bk. Zencânî, Tahrîcü̉l-fürû', s. 38-39. 
yöneldiği (el-istikmâl bi’l-gayr) iddiasının söz konusu olacağını savunmuşlardır. ${ }^{54} \mathrm{Bu}$ görüşün ardında, ilâhî kudrete vurgu ve tenzih ilkesini muhafaza düşüncesi yer almaktadır. Bununla beraber mutlak kudret düşüncesinin ahlâkî sonuçları izlendiğinde, yaptığı fiillerde "sorumsuz" veya "sorgulanamaz" bir tanrı fikrine varılabilir. Diğer bir ifadeyle, varlık bakımından zorunlu olmama, ahlâkî açıdan da zorunlu olmamayı doğurur. ${ }^{55}$ Belki de bu sebeple Mútezile âlimleri Allah’n fiillerinin illetli olduğunu savunmuş ve aksi durumda ilâhî fiillerin hikmetsiz ve abes işler olarak görülmesi gerekeceğini söylemişlerdir. ${ }^{56}$ Mu'tezile’nin bu görüşü usul tartışmalarında kısmen yanlış anlaşılmış (ya da kasten yanlış yorumlanmış) ve onların, bir şey akıl tarafından güzel görünüyorsa Allah’n onunla ilgili olumlu bir hüküm koymasını aklen zorunlu gördükleri şeklinde değerlendirilmiştir. Oysa İbnü’lHümâm’n (ö. 861/1457) ifade ettiği üzere, onların görüşlerinin özü şöyledir: İlk olarak akıl bir fiilin ihtiva ettiği güzellik veya çirkinliği idrak eder, daha sonra Allah’n o fiille ilgili olarak tam da aklın idrak ettiğine uygun bir hükmünün bulunduğunu ve o hükme binaen sevap ya da günah terettüp ettiğini idrak eder. Yani onlar aklın Allah’ bağlayacak bir hüküm koyacağını iddia etmiş değildirler. ${ }^{57}$ Mu'tezile’nin bu görüşünün arka planındaki düşünce, ilâhî fiillerin muhakkak bir hikmete (daha çok adalet ilkesi) mebni olmasıdır. Eğer âlemin yaratılması zorunlu değilse -ki filozoflar karşısında bütün kelâmcılar bu konuda müttefiktir- bu durumda Allah’̉n, hiçbir ihtiyacı olmadığı halde âlemi niçin yarattığı sorusu akla gelmektedir. Eş́arîler bu soru karşısında, ilâhî fiillerin ardında illet aramanın anlamsızlığını savunurken, Kādî Abdülcebbâr bu soruya, muhtaçlık ile tercih arasında doğrusal bir ilişkinin olmadığı ve tercih muhtaçlı̆̆ gerektirmeyeceği gibi, müstağni olmanın da tercihi engellemeyeceği cevabını vermektedir. ${ }^{58}$ Mu'tezile’nin ve özel olarak aslah taraftarının söz konusu zorunluluk kavrayışına varmasının bir diğer sebebi, gaibin şahide kıyası yöntemi gereğince fâilin kendisi-

54 Eş'arî mezhebinin görüşünü Şehristânîş̧öyle özetlemektedir:"Allah, içindeki cevherleri, arazları vesair tür ve mahlûkatıyla birlikte bu âlemi, kendisini fiile hamledecek bir illet olmaksızın yaratmıștır. Bu illetin kendisine faydalı olmasının ya da olmamasının takdir edilmesi, durumu değiştirmez. Çünkü O’nun zatı fayda ve zararı kabil değildir. Aynı şekilde bu illetin Allah'tan başkasına fayda sağladığını düşünmek de durumu değiştirmez. Çünkü Allah’ı fiile sevkedecek hiçbir etken (bâis) söz konusu değildir. Bu sebeple onun fiillerinin garazı da yoktur, onu fiile sevkedecek bir etken (hâmil) de! Aksine her şeyin illeti, O’nun yaratmasıdır, O’nun yaratmasının ise illeti yoktur" (Nihâyetüll-ikdâm, s. 397).

Türker, "İlâhî Fiillerin Nedenliliği Sorunu", s. 3.

56 Bk. Şehristânî, Nihâyetü'l-ikdâm, s. 397 vd.

57 Bk. İbn Ebû Şerîf, el-Müsâmere, s. 158 vd.

58 Bk. Kādî Abdülcebbâr, el-Mugnî, XI, 98 (nakleden: Türker, "İlâhî Fiillerin Nedenliliği Sorunu", s. 13). 
ne veya başkasına yararı olmayan bir fiili abes kabul etmesidir. Dolayısıyla Mu'tezile’ye göre ilâhî fiil, hikmet olması için mutlaka bir başkasına faydalı olmak zorundadır. ${ }^{59}$ Mâtürîdîler ise orta bir yol izlemişler, bir taraftan ilâhî fiillerin tamamının (bir kısmı bizim için kapalı dahi olsa) maslahat için yapılmış (hikmete mebni) olduğunu ifade ederken, diğer taraftan Allah’a herhangi bir zorunluluk atfetmenin yanlış olduğunu vurgulamışlardır. ${ }^{60}$

Fahreddin er-Râzî bu tartışmanın kelâm ilmine taalluk eden kısmında Eşarầ mezhebini savunduğu için, konumuzla ilgili âyetin tefsirinde de, âyeti ilâhî fiillerin illetsizliği görüşüne delil olarak göstermiştir. Eş́arîler’ in bu âyet dışında konuyla ilgili diğer delilleri şöyledir:

1. Eğer Allah herhangi bir fiilini bir illete binaen yapacak olsaydı, o zaman o illetin ortaya çıkması için de bir illete ihtiyaç duyulacaktı. Böylece sonsuz geri gidiş (teselsül) durumuna düşüleceği için, illetsiz bir şeyin kabul edilmesi gerekecektir ki buna en lâyık olan da Allah’ın zatı ve sıfatlarıdır.

2. Eğer Allah herhangi bir fiilini bir illet ve amaca binaen yapıyorsa, o zaman bu illet ya zorunlu ya da mümkün olmalıdır. Eğer bu illet zorunlu ise, o zaman illetin gerektirdiği fiili yapmak da zorunlu olacaktır. Bu durumda da Allah, fâil-i muhtar (kendi iradesiyle fiil yapan zat) değil, zatı itibariyle zorunluluk altında olacaktır. Eğer söz konusu illet mümkün ise, o zaman o illet yine Allah'a ait bir fiil olacaktır ve o illetin bir fiil olarak yapılması da bir başka illeti gerektirecektir. Bu durumda yine bir teselsül söz konusu olacaktır ki, bu da muhaldir.

3. Eğer Allah’̉n âleme yönelik fiilinin illeti ezelî ise o zaman O’nun âleme yönelik fiili de ezelî olacaktır ki bundan âlemin kıdemi (ezelîliği) sonucu çıkar. Eğer bu illet muhdes (sonradan yaratılmış) ise, o zaman da bir başka illete muhtaç olacaktır. Bu durumda da teselsül (sonsuz geri gidiş) söz konusu olacaktır.

4. Bir kimse bir amaca ulaşmak için bir fiil yapıyorsa, ortada iki ihtimal vardır: Ya amaca o fiilin aracılığı olmaksızın da ulaşabilme imkânına sahiptir ya da bu imkâna sahip değildir. Eğer fiilin aracilı̆̆ olmadan amaca ulaşabiliyorsa, fiilin varlığı abes olacaktır. Ulaşamıyorsa, o zaman da acziyet içindedir ki bu durumun Allah için düşünülmesi muhaldir. Fakat acziyet bizler için muhal değildir, bu sebeple bizim fiillerimiz amaçlarla mualleldir. ${ }^{61}$

5. Eğer Allah herhangi bir fiilini bir illet ve amaca binaen yapıyorsa, bu amaç ya bizzat Allahı̀n kendisine yönelik olmalıdır ya da kullara. Birincisi

59 Türker, "İlâhî Fiillerin Nedenliliği Sorunu", s. 5.

6o Bk. Mâtürîdî, Kitâbü't-Tevhîd, s. 343-51; Şelebî, Ta 'lîlü'l-ahkâm, s. 97.

61 Fahreddin er-Râzî, Mefâtîhu’l-gayb, XXII, 155-56. 
muhaldir, çünkü Allah fayda ve zarardan münezzehtir. O halde amaç kullara yönelik olmalıdır. Kullara yönelik amaçların tahsili ise Allah için herhangi bir vasıta olmadan da yapılabilecek bir şeydir. Dolayısıyla O’nun herhangi bir şeyi bir amaç için yapmış olması imkânsızdır. ${ }^{62}$

6. Eğer Allah herhangi bir fiilini bir illet ve amaca binaen yapıyorsa, bu amacın varlığı ya da yokluğu Allah için ya eşit olmalı ya da eşit olmamalıdır. Eğer bu iki durum onun için eşit ise, zaten ortada bir amaç olması söz konusu olamaz. Aksi durumda ise (yani amaca ulaşıp ulaşmamanın birbirine eşit olmaması durumunda) O’nun o fiili yapmadan önce, söz konusu amaca (hedefe) vâsıl olmadığını, dolayısıyla bir eksiklik taşıdığını, o fiiliyle bu eksikliğini gidermiş olduğunu (el-istikmâl bi'l-gayr) düşünmek gerekecektir ki Allah hakkında böyle bir şey düşünmek muhaldir. Eğer söz konusu amaca ulaşıp ulaşmamak Allah için eşitse, fakat bu amaç kullara yönelik olduğu (yani o amaca ulaşmak kullar için bir önem arzediyor olduğu) için o fiili yapıyorsa, o zaman bu argüman geçersiz olacaktır. Ancak Fahreddin er-Râzî buna karşıllık şunu ifade eder: Eğer kulun söz konusu amaçtan hâsıl olacak yararı elde etmesi ve etmemesi Allah için eşit değilse, o zaman yukarıdaki taksim yine söz konusu olacak ve (el-istikmâl bi'l-gayr) durumu ortaya çıkacaktır.

7. Varlık âlemi dediğimiz şey iki varlıktan oluşur. Biri Allah’̉n zatıdır, diğeri de onun mülküdür. Kendi mülkünde tasarrufta bulunan bir zata ise "Şunu niçin yaptın?" gibi bir soru sorulmaz.

8. Bir başkasına, "Bunu niçin yaptın?" diye sormak, ancak onu o fiilden alıkoyma kudretine sahip olan biri tarafından sorulduğunda anlamlı ve güzel olur. Oysa Allah’a karşı böyle bir durum söz konusu olamaz. ${ }^{63}$

9. Tâlil, lafzî olabileceği gibi mânevî de olabilir. İnsanlar eşyanın hakikatini bilemezler, metinlerden anlaşılan tek şey, onların lafzî mânalarıdır. $\mathrm{Bu}$ yüzden, Kur'an âyetlerinde geçen tâlil ifadeleri, sadece lafzî olarak tâlildir. ${ }^{64}$

Fahreddin er-Râzînin sıraladığı bu delillerin her birine çeşitli cevaplar verilmiştir. Ancak onun bütün bu tartışmaları bu âyetin tefsirinde yapması, âyetin tefsiri ile doğrudan ilgili görünmemektedir. Çünkü âyetin bu konularla ilişkilendirilmesi oldukça zorlamadır. Kaldı ki ilâhî fiillerin tâlil edilebileceğini savunan âlimler, Allah’̉n sorguya çekilebileceğini iddia etmiş değillerdir. ${ }^{65}$ Ancak Fahreddin er-Râzî ve diğer Eşarâi âlimler âyetteki "sual" (sorma) ifadesini, "fiilin sebebini, hikmetini öğrenmek üzere sormak" şeklin-

62 Fahreddin er-Râzî, Muhassal, s. 205.

63 Fahreddin er-Râzî, Mefâtîhu’l-gayb, XXII, 155-56.

64 Fahreddin er-Râzî, Mefâtîhu'l-gayb, XXVIII, 232-33.

65 Bk. Şelebî, Ta'lîlü’l-ahkâm, s.102. 
de anlamışlardır. Oysa birçok tefsirde bu ifadenin, beyan, istikşaf, öğrenme gibi amaçlarla soru sormak değil, ihticac (karşı çıkma, itiraz) ve muhasebe anlamında sormak anlamına geldiği ifade edilmiştir. ${ }^{66}$

Fahreddin er-Râzînin Eşarâi mezhebi penceresinden bakarak yorumladığg bu âyet çerçevesinde, Mu'tezile âlimlerinin değerlendirmeleri de, muhteva ve hedef itibariyle tam aksi istikamette olsa da, yorum mantığı açısından aynı minvalde seyretmektedir. Onlar da âyetin nüzûl ortamındaki vurgusunu esas almak yerine, "lâ yüs'elü ammâ yef'al" ifadesini kendi mezhepleri uyarınca yorumlamışlardır. Fahreddin er-Râzî onların görüşlerini altı maddede özetlemiştir. Bazıları mükerrer olan bu hususları şöyle aktarmak mümkündür:

Eğer hüsün ve kubuh (güzellik ve çirkinlik) Allah tarafından yaratılan şeyler ise o zaman bu âyette ifade edildiği gibi "Allah yaptıklarından sorulmaz" denilmemesi gerekirdi. Zira o zaman Allahın methi gerektiren şeylerde methedilmesi, zemmi gerektiren şeylerde zemmedilmesi gerekirdi. ${ }^{67}$ Her fiilin yaratıcısı Allah ise, o zaman Allah’ın insanları hesaba çekmemesi, yaptıklarından dolayı onları sorumlu tutmaması gerekirdi.

Allah Kur'an'da birçok yerde kullarının kendisine karşı hüccetlerinin ve iddialarının olabileceğinden söz etmiştir. ${ }^{68}$

Kiyamet gününde Allah bir kula, "Niçin bana isyan ettin?" diye sordugunda, kul cevap olarak, "Allahım! Sen beni kâfir olarak yarattın, benden kudretimi aşan bir şey yapmamı (iman etmemi) istedin, ama benimle iman arasına engel koydun" diyecek olsa, Cebriyye mezhebinin görüşüne göre doğru söylemiş olacaktır. Allah da, "O gün doğru sözlülere sadakatleri fayda edecektir" buyurmaktadır. 69 Dolayısıyla bu kişinin sözü (eğer Cebriyye’nin görüşü doğruysa) kendisine fayda etmelidir. Buna karşlık, "Allah o kişiye bunları söyleme izni/firsatı vermez" denilecek olsa, buna cevaben şöyle denilir; "Allah, o kişiye fırsat verecek olsa, onun bu savunmayı yapacak olduğunu bilmektedir. Bu da (Cebriyye açısından) söylenecek bir sözün kalmadığı noktadır."7o

Görüldüğü gibi Mútezile’nin yorumunda da ilgili âyetler nüzûl ortamından koparılmış ve lafzî olarak okunmuştur. Ancak bunlara cevap sadedinde Fah-

66 Bk. Zeccâc, Meani'l-Kur'ân, III, 388; Semerkandî, Bahrül-ulûm, II, 365; İbn Âşûr, etTahrîr, XVII, 46.

67 Bk. Kādî Abdülcebbâr, Tenzîhü'l-Kur'an, s. 26o; Fahreddin er-Râzî, Mefâtîhu'l-gayb, XXII, 157.

68 Meselâ bk. en-Nisâ 4/165; Tâhâ 20/134.

69 el-Mâide 5/119.

70 Bk. Fahreddin er-Râzî, Mefâtîhu'l-gayb, XXII, 157. 
reddin er-Râzînin, söz konusu âyetleri nüzûl bağlamına irca etmek şeklinde bir itirazı olmamış, aksine, Allah’ın fiilleri konusunda "neden, niçin?" gibi soruların (talebü'l-limmiyye) söz konusu olamayacağını söylemekle yetinmiştir.

Âlûsî bu âyeti tefsir ederken önce, âyetin ne gibi bir soru ya da itiraza cevap teşkil ettiğini tartışmıştır ki kanaatimizce bu yaklaşım son derece önemlidir. Çünkü bir sözün mânasının bütün gönderim ve hedefleriyle birlikte anlaşılabilmesi için, hangi ortamda ve nasıl bir soruya (ya da duruma) cevap olarak söylenmiş olduğunu bilmek gerekmektedir. Âlûsî de burada bu soruyu sormuş ve muhtemel iki cevap üzerinde durmuştur. Bunlardan birincisi, kâfirlerin (müşrikler) Allah hakkında uygunsuz vasıflar öne sürmeleri ve bu durum karşısında müminlerin, "Madem Allah sonsuz kudret sahibi yegâne yaratıcıdır, o halde niçin şu kâfirleri yaratmıştır, niçin bunların bu uygunsuz sözlerine engel olmamaktadır?" gibi sorular sormuş olmasıdır. Buna cevap olarak da, "lâ yüs'elü ammâ yef'al" denilmiş olmaktadır. ${ }^{71}$

Âlûsînin dile getirdiği bu ihtimal pek mümkün görünmemektedir. Çünkü âyetin siyakı müşriklere cevap mahiyetindedir. Onlara cevap verilirken, arada kısacık bir cümlede muhatabın değişmiş olması, zorlama bir yorum gibi görünmektedir. Üstelik eğer müminler böyle bir soru sormuş iseler, bu sorunun Allah'a karşı isyankâr bir tavır içinde değil, meselenin sırrını ve hikmetini anlamaya yönelik bir soru olması icap eder. Böyle bir soru karşısında ise, "Kimse Allah'ı sorguya çekemez" anlamına gelen "lâ yüs'elü ammâ yef'al" cevabının verilmesi, diyalogun doğası açısından pek mümkün görünmemektedir. Ancak bu ifade, yukarıda referanslarını verdiğimiz üzere ilk dönem tefsirlerinde "Kimse Allah’ı sorguya çekemez" anlamında anlaşıldığı ve âhiretteki hesap meselesiyle ilişkilendirildiği halde, ilerleyen dönemlerde ilâhî fiillerin illetsizliği meselesiyle ilişkilendirilmiş ve buna bağlı olarak, Allah’ın yaptığ fiillerin sebepsiz olduğu, onların sebep ve hikmetlerini aramanın nâfile olduğu düşünülmüştür. Âlûsî de bir anlamda meseleyi bu noktaya getirmiş görünmektedir.

Âlûsî ikinci ihtimal olarak, bu ifadenin herhangi bir soruya, itiraza ya da duruma cevap teşkil etmediği şeklindeki görüşü zikretmekte ve bu durumda cümlenin kâfirler için bir vaîd/tehdit anlamı taşıdığını ifade etmektedir. Ardından ilâhî fiillerin illeti meselesine girmekte, "ve hüm yüs'elûn" ifadesindeki "hüm" (onlar) zamirinin "kullar" anlamına geldiğini, dolayısıyla âyetin, "kulların ilâhî fiillerin illetini soramayacaklarını" ifade ettiğini savunmaktadır. Yine Âlûsî, bu ifadenin âhirette kulların amellerinden hesaba çekileceği anlamına geldiğini söyleyen Zeccâc’n (ö. 311/923) görüşünü ak-

Bk. Âlûsî, Rûhu'l-meânî, XVII, 28. 
tarmakta, fakat diğer görüşün daha evlâ olduğunu ifade etmektedir. Her ne kadar Zeccâc’’n görüşü esas alındığında âyette kâfirlere tehdit vurgusunun daha açık ve güçlü olduğunu kabul etse de, Âlûsînin genel anlamda bu âyeti umumuna hamlettiğini ve ilâhî fiillerin tâlil edilmesi meselesiyle ilişkilendirdiğini söylemek mümkündür. Nitekim kendisi, önce illeti kabul edenlerin görüşlerini İbn Kayyim el-Cevziyye'den alıntılarla kısaca özetledikten sonra karşıt görüşte olanların delillerinin özünü de sunmuştur. ${ }^{72}$

Buna göre Eş‘arîler, iki zıt ihtimal söz konusu olduğunda Allah’ın bu iki ihtimalden birini tercih etmesini sadece iradenin taalluk etmesine bağlarken, illeti kabul edenler bu tercihe sebep olacak bir illetin bulunması gerektiğini söylerler. Bu sebebe terminolojide "muhassıs" denilmiştir. Mu'tezileye göre muhassıs, tercihin sonucunun faydalı olacağına dair ilâhî ilimdir. Ancak bu argümana karşı Eş́arîler’in şöyle bir itirazı olacaktır:

Allah’̉n ilmi bütün varlığa taalluk etmektedir, eğer O’nun herhangi bir şeyin yaratılmasının faydalı olacağına dair bilgisi "muhassıs" (tercih sebebi) olsaydı, o zaman O’nun fiili ihtiyarî değil, zorunlu olurdu ki bu durum, Allah’n özgür irade sahibi olmadığını savunan filozofların görüşlerine kapı aralayacaktır.

Bu itiraz Mâtürîdî mezhebinin görüşlerine karşı da geçerlidir. Çünkü ilâhî zat zorunlu olarak ilim sahibi olmayı gerektirir, ilim (faydalı ve maslahat içeren şeylere dair ilim) faydalı ve maslahat içeren şeylerin yaratılması yönünde bir iradenin taalluk etmesini gerektirir, irade ise böyle bir fiilin vukuunu gerektirir. Böylece ilâhî zat fâil-i muhtar (özgür iradeyle fiil işleyen) değil, mecbur olmuş olur. Mâtürîdîler'in buna verdiği cevap şöyledir: Fayda ve maslahata dair ilâhî bilginin faydalı ve maslahat içeren şeyleri irade etmeyi icap ettirmesi söz konusu değildir; aksine bu ilâhî bilgi bir tercih sebebidir, ama "Allah’ın zatı açısından, vücûb derecesine varmayacak ölçüde bir tercih sebebidir” (مرجح ترجيحا غير بالغ إلى حد الوجوب). Dolayısıly ilâhî fiillerin, onlara sebep olabilecek birtakım amaçlarla/hikmetlerle illetlendirilmesinin Allah'a zorunluluk atfetmek gibi bir anlama gelmesi söz konusu değildir. ${ }^{73}$ Buna karşllık şöyle bir itiraz mümkündür:

Tercih sebebi olan bir etken, fâili tercihe (fiil) zorlayacak ölçüde değilse, bu durumda tercihe şayan olan seçeneğin bir defasında gerçekleşip (aynı tercih sebebinin mevcut olduğu) diğer bir defada gerçekleşmemesi

72 Âlûsî, Rûhu'l-meânî, XVII, 29.

73 Âlûsî, Rûhu'l-meânî, XVII, 30. 
mümkündür. Hangisinde söz konusu seçeneğin gerçekleşeceğinin hususen tercih edilmesi, ilk tercih sebebi dışında bir etkenin ilâvesiyle oluyorsa, o zaman ilk tercih sebebi artık tercih sebebi sayılmaz. ${ }^{74}$

Âlûsî bu itirazın şu iki gerekçeden dolayı geçersiz olduğunu ifade etmektedir.

Birincisi; bu itiraz, illet ile mâlûl arasında tam bir mutabakatın bulunduğu durumlarda (yani bir fiilin tamamen bir illete bağlı olması durumunda) geçerli olabilir, yoksa fiilini icra ederken ihtiyar sahibi olan bir fâil mevzubahis iken, bu itiraz geçerli olamaz... İkincisi; belli bir zamanda tercihe sebep olan etken, bir başka zaman öyle olmayabilir, hatta maslahata aykırı olabilir... ${ }^{75}$

Câbirînnin ifadesiyle bu mesele, beyanî Arap aklının, Kant'in antinomilerine (saf aklın çelişkilerine) benzer şekilde karşılaştığı ilk büyük antinomidir. İlâhî fiillerin illetli olduğu kabul edildiği takdirde konu Allah’n bir başka şeye muhtaç oluşu meselesiyle ilgisi açısından ilâhî kudrete taalluk etmekte ve illetin kabulü kudretin nefyine sebep olmakta, illetin reddedilmesi durumunda ise ilâhî fiillerin hikmetsiz oluşları meselesinden dolayı konu yine ilâhî "kemal" ve "ilâhî kudret"e taalluk etmektedir. Böylece her iki durumda da ilâhî kudretin nefyi söz konusu olmaktadır. ${ }^{76}$ Bizi ilgilendiren nokta Âlûsînin âyetin tefsirinde konuyu nüzûl vasatından bağımsız bir şekilde ele almış, ilgili kelâm tartışmalarını özetlemiş olmasıdır. Yakın dönem müfessirlerinden biri olan Şevkânî (ö. 1250/1834) ise klasik görüşlerden ikisini vermekle yetinmiş, kelâm tartışmalarına girmemiştir. ${ }^{77}$ Âyetteki konunun kelâm tartışmalarına çekilmesinin sakıncasına işaret eden Derveze (ö. 1404/1984) âyetin katı bir kadercilik anlayışının gerekçesi olarak sunulmasının yanlış olduğunu özellikle ifade etmekte, âyetin siyakının ve ruhunun bu tür anlamlara muhtemil olmadığını, aksine burada Allah'tan başka varlıkları ilâh edinen müşriklere cevap maksadının söz konusu olduğunu belirtmektedir. Yine onun önemle vurguladığı bir başka husus, müşriklerin Allah’a soru sorabileceklerini ya da putların (meleklerin) böyle bir yetkiye sahip olduklarını asla düşünmedikleri, aksine putları Allah katında kendilerine aracı olarak telakki ediyor olduklarıdır. Kısacası Derveze'ye göre âyetteki vurgunun ve mesajın bu çerçevenin dışına çıkarilmaması gerekmektedir. ${ }^{78}$

74 Âlûsî, Rûhu'l-meânî, XVII, 30.

75 Âlûsî, Rûhu'l-meânî, XVII, 30.

76 Bk. Câbirî, Bünyetü'l-akli'l-Arabî, s. 159.

77 Şevkânî, Fethu'l-kadîr, III, 402-3.

78 Derveze, et-Tefsîrül-hadîs, V, 236. 


\section{3. Âyetin İç ve Dış Bağlamı}

\section{1. İç Bağlam: Siyak-Sibak}

İncelemekte olduğumuz âyet, sûrenin 23. âyetidir ve sûrenin başından beri konu, müşriklerin tenkididir. Özellikle 11. âyetten itibaren, geçmişte birçok zalim/müşrik kavmin helâk edilmiş olduğu vurgusu yapılmakta, 19. âyetten itibaren de, kâinattaki her şeyin ilâhî kudret altında olduğu, bu yüzden de Allah dışında hiçbir varlığın kulluk edilmeye lâyık olmadığı ifade edilmektedir. 19 ve 20. âyetlerde müşriklerin melekleri Allah’n kızları olarak görmelerine cevap verilmekte ve Allah katında bulunan (وَمَنْ عَنْدَهُ ) o meleklerin ${ }^{79}$ Allah'a kulluk etmekten hiçbir şekilde kaçınmadıkları ifade edilmektedir. Bu âyetlerle burada incelemekte olduğumuz 23. âyetin arasına giren 21. âyetteki أَم اتَّخَذُواُ

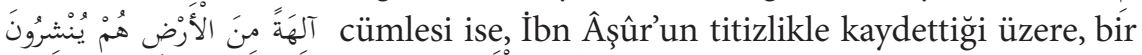

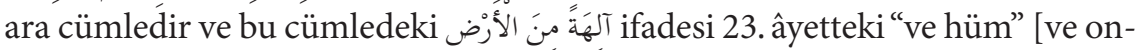
lar] zamirinin mercii değildir. ${ }^{86}$ Yani 23. âyetteki "ve hüm yüselelûn" ifadesinde geçen "ve hüm" [ve onlar] zamiriyle, 21. âyette sözü edilen müşriklerin yeryüzünde kendilerini ilâh edindikleri varlıklar (putlar) değil, 19. Âyette وَمَنِ عَنْدَ ifadesiyle sözü edilenler, yani müşriklerin Allahın kızları olarak telakki ettikleri melekler kastedilmektedir. ${ }^{81}$ Dolayısıyla 23. âyetteki "ve hüm yüs'elûn" ifadesine, "Kullar yaptıklarından sorulurlar" ya da "Putlar yaptıklarından sorulurlar" şeklinde anlam verilmesi doğru değildir. Bu ifadenin anlamı, "Müşriklerin Allah’ın kızları olarak telakki edip ibadet ettikleri Allah katındaki melekler dahi hesaba çekilecektir, dolayısıyla onlara kulluk etmek beyhudedir" şeklindedir. Çünkü kulların fiillerinden hesaba çekilecekleri zaten müsellem ve bedîhî bir durumdur (لأن أولئك لا جدوى للإخبار بأنهم يسألون إذ لا يتردد في العلم بذلك ألكان (أحد ${ }^{82}$ ve buradaki konu açısından bahs-i diğerdir. Putların hesaba çekilme-

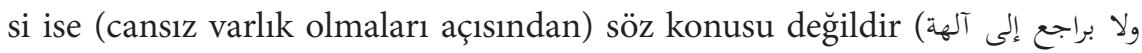
(من الأرض لعدم صحة سؤالهم si hakkında yukarıda takdir ettiğimiz anlamın dışındaki ihtimaller, metnin

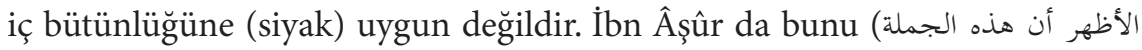

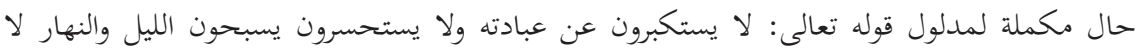
يغترون), “Açıktır ki bu cümle, 'Onlar/melekler Allah'a ibadetten ne kibirlenir ne de yüksünürler, bıkıp usanmadan gece gündüz O’na ibadet ederler' âyetinin anlamını tamamlayıcı bir ifadedir" cümlesiyle sarâhaten ifade etmiştir. ${ }^{84}$

$79 \mathrm{Bu}$ ifadenin melekler anlamına geldiği, İbn Âşûr'un yanı sıra Şiî müfessirlerden Kummî tarafından da ifade edilmiştir (Bk. Kummî, Tefsîrü̉l-Kummî̀, II, 68).

8o İbn Âşûr, et-Tahrîr, XVII, 37.

81 İbn Âşûr, et-Tahrîr, XVII, 45.

82 İbn Âşûr, et-Tahrîr, XVII, 45.

83 İbn Âşûr, et-Tahrîr, XVII, 45.

84 İbn Âşûr, et-Tahrîr, XVII, 45. 


\subsection{Dış Bağlam: Müşriklerin İnanç Dünyaları}

Enbiyâ sûresinin Mekke'de nâzil olduğu konusunda ittifak vardır. ${ }^{85}$ Zaten âyetin siyakı, yukarıdaki değerlendirmemizde görüldüğü üzere, tamamen müşriklere reddiye sadedindedir. O halde burada hitap müşriklere yönelik olmalıdır. Bu durumda da müşriklerin inançlarının ve düşüncelerinin, Allah’a soru sormayı ya da O’na karşı çıkmayı mümkün kılıp kılmayacağına bakmak icap etmektedir. Müşrikler Allah’ın yaratıcılığına, kudretine ve ulûhiyyetine inanmakta, O’na ulaşmak için başka varlıkları aracı kabul etmektedirler. Onların Allah inancındaki problem, doğrudan kulluk yerine şirk koşmalarıdır. Fakat onlar bunu yaparken doğru hareket ettiklerini düşünmekte ve kendilerini tamamen haklı görmektedirler. Onların Kur’an tarafından "müşrik" olarak nitelendirilmeleri, yorumlayııı bir ifade tarzıdır. Çünkü onlar kendilerini müşrik görmedikleri gibi, tam aksine doğru yolda görmektedirler. ${ }^{86} \mathrm{Ayrıca}$ onlar Allah'a şirk koşarken bile bunu daha dindar olmak ve Allah’ tâzim etmek gibi gerekçelerle yapmaktadırlar. Râzînin aşağıdaki cümlesinde ifade ettiği gibi, şirk mantığının altında şu değerlendirme yer almaktadır:

Putlara tapanlar şöyle derlerdi: "Âlemin ilâhı, bizim kendisine ibadet etmemiz uygun düşmeyecek kadar yücedir, biz ise gök cisimlerine ve şu putlara ibadet ederiz. Bu gök cisimleri ve putlar da o en yüce ilâhın kullarıdırlar". ${ }^{87}$

Diğer taraftan Mekke ve çevresindeki Araplar’ın Câhiliye döneminde diğer Araplar arasında dindarlıklarıyla ön plana çıktıkları, kendilerini dinin bağlısı ve hâmisi olarak gördükleri, onların hums ${ }^{88}$ ve hille ${ }^{89}$ kavramlarından da anlaşılmaktadır. Mekke ve çevresindeki bazı kabileler "hums" adı verilen bir gruba mensup iken Medine Arapları dahil diğer birçok kabile "hille" adı

85 Bk. Mâtürîdî, Te’vîlâtü'l-Kurân, IX, 255; Zemahşerî, el-Keş̧̧âf, IV, 124; İbn Atıyye elEndelüsî, el-Muharrerü'l-vecîz, IV, 74; Kurtubî, el-Câmi', XIV, 170.

86 Fahreddin er-Râzî̀, A'râf sûresinin 28. âyetinin tefsirinde şu ifadelere yer vermektedir: "Bil ki müşrikler, yaptıkları davranışların Allah’ın emri olduğunu söylerlerken aynı zamanda o davranışların kötü olduğunu düşünüyor değillerdi, çünkü böyle bir şeyi aklı başında hiç kimse kabul etmez. Aksine âyetin maksadı; bu davranışların aslında kötü olduğunu, fakat müşriklerin bunları Allah'a itaat ve ibadet olarak telakki ettiklerini, Allah’ın bu davranışları emrettiğini düşündüklerini anlatmaktır” (Mefâtîhu'l-gayb, XIV, 59).

87 Fahreddin er-Râzî, Mefâtîhu'l-gayb, XX, 85.

88 Hums kelimesi “dine bağlılık ve dinde aşırılık" anlamına gelir. Mekkeliler'in kendilerini böyle isimlendirmelerinin sebebi, inançlarına sıkı bağlılıklarıdır. Bk. Zebîdî, Tâcülarûs, XV, 555.

89 Bk. İbn Hişâm, es-Sîretün-nebeviyye, I, 228-29. 
verilen diğer bir gruba mensup sayılmıştır. Hums grubu Mescid-i Harâm’n sahibi olarak görülüp daha dindar kabul edilmiş, ${ }^{90}$ bunların dinî ve dünyevî olarak diğer gruptan üstün ve ayrıcalıklı oldukları düşünülmüştür. ${ }^{91}$ Kur’an, Mekkeli müşriklerin (hums grubu) Kâbe’nin bakımını yapmak, hacılara su dağıtmak, misafir ağırlamak, kısacası Mescid-i Harâm’n hizmetkârları olmak gibi niteliklerle övündüklerini kaydetmekte ve bu hususta onları eleştirmektedir. ${ }^{92}$ Bu bilgiler dikkate alındığında, Mekke müşriklerinin Allah’a karşı çıkmak, O’na karşı had bilmezlik yapmak gibi bir tavır içinde olduklarını düşünmek imkânsız görünmektedir. Öyleyse onlara, "Allah yaptıklarından sorulmaz" denildiğinde, onların böyle bir iddiada bulunduğu kastediliyorsa, bu tarihî bağlam dikkate alındığında, müşrikler açısından böyle bir ifadenin hiçbir hakiki karşılığı olmayacaktır. Buna karşılık müşriklerin Allah nezdinde bazı varlıkları aracı telakki ettikleri, onların rızasını kazanmak suretiyle Allah'a yakınlaşmayı düşündükleri, bunu giderek aşırılaştırıp o varlıklara yönelik tâzim ve takdis duygularını şirk derecesine vardırdıkları göz önünde bulundurulduğunda, "Onlar yaptıklarından sorulurlar" ifadesiyle, yukarıda İbn Âşûr'dan da iktibas ettiğimiz gibi, müşriklerin takdis ettikleri meleklerin kastedildiği anlaşılacaktır. Bu durumda âyet, onların melekleri Allah’’n kız-

90 İbn Hişâm (ö. 213/828) bu durumu şöyle anlatmaktadır: Kureyşliler -Fil yılından önce mi, sonra mı bilmiyorum- bir hums düşüncesi icat ettiler ve şöyle dediler: Bizler İbrâhim'in evlâtları, Harem ehli, Beytullah’n dostları, Mekke’nin sakinleriyiz. Araplar'dan hiç kimse bizim sahip olduğumuz haklara sahip olmadığı gibi bizim konumumuza da sahip değildir. Araplar hiç kimseye bizlere tanıdıkları bu mevkiyi tanımazlar. O halde (ey Mekkeliler!) sizler de Harem dışında (hille) hiçbir şeye Harem’e gösterdiğiniz saygıyı ve tâzimi göstermeyin. Eğer böyle yaparsanız sizi hafife alırlar ve "Bunlar Harem'e saygı gösterdikleri gibi Harem dışında da saygı gösteriyorlar" derler. İşte bu sebeple Mekkeliler (Harem dışında kaldığı için) Arafat'ta vakfe yapmayı ve oradan akın akın inmeyi (ifâzâ) terkettiler. Bununla beraber onlar Arafat'ta vakfe yapıp oradan akın akın inmenin hac menâsikinden (meşâir) ve İbrâhim dininden olduğunu kabul ve itiraf ediyorlardı. Diğer Araplar'ın Arafat vakfesi yapıp oradan (Müzdelife ve Mina'ya) akın akın inmeleri gerektiğini düşünüyorlar, fakat kendileri için şöyle diyorlardı: "Biz Harem ehliyiz, bu yüzden Harem’in dışına çıkıp da, Harem’e gösterdiğimiz tâzimi başka bir yere göstermemiz uygun olmaz” (es-Sîretün-nebeviyye, I, 225, 226).

91 İbn Hişâm bu hususu şöyle anlatmaktadır: “(Kureyşliler) şöyle dediler: 'Hille ehli hac veya umre için Mekke'ye geldikleri zaman yanlarında getirdikleri yiyecekleri yiyemezler, Mekke'ye geldiklerinde ilk yapacakları tavafı ancak hums ehline ait elbiselerle yapabilirler. Eğer böyle bir elbise bulamazlarsa çıplak tavaf ederler. Eğer hille ehli biri hums ehlinden alacak bir elbise bulamaz ve çıplak tavaf etmekten de çekinir, bu sebeple kendi elbisesiyle tavaf ederse, tavaftan sonra bu elbisesini çıkarıp atmalı, bir daha onu giymemelidir. Artık o elbiseye ne o ne de bir başkası dokunabilir.' Araplar bu elbiseye 'el-lekâ' adını vermişlerdir. Böylece Kureyşliler Araplar'a bu kuralları dayatmışlar, onlar da bunu kabullenmişlerdi” (es-Sîretün-nebeviyye, I, 228-29).

92 el-Bakara 2/17-19. 
ları olarak görmeleri ve onlardan medet ummalarına cevap teşkil etmekte, meleklerin âhirette Allah tarafından hesaba çekilecek varlıklar olduklarını, bu sebeple de kendilerinden medet umulamayacağını vurgulamıs olmakta, buna karşılık Allah’ın hesaba çekilemez kudret olduğunu hatırlatarak sadece O’na kulluk edilmesi gerektiğini söylemektedir.

\section{Sonuç Yerine: İbn Âşûr'un Yorumu Eşliğinde Âyetin Tefsiri}

İncelediğimiz âyet, nüzûl dönemi itibariyle, Mekke müşriklerinin melekleri Allah’n kızları olarak görüp onlardan âhirette medet umuyor ve bir anlamda onları mâbut seviyesinde telakki ediyor olmalarına cevap veren ve söz konusu meleklerin Allah katında birer kul olduklarını, âhirette hesaba çekileceklerini vurgulayan bir mahiyet arzederken, kelâm tartışmalarının alevlenmesiyle birlikte bu âyetin anlam alanı tamamen değişmiş ve ilâhî fiillerin nedenliliği/nedensizliği meselesinde konuşlandırılmaya başlanmıştır. Fahreddin er-Râzî ve Âlûsî gibi müfessirlerin eserlerinde artık tamamen bu mecraya çekilen âyet, diğer birçok tefsirde de önemli ölçüde nüzûl ortamının dışında anlaşılmıştır. Bu durumu bu yazıda, "tefsir ilmi üzerinde kelâm tartışmalarının etkisi” olarak tesmiye edilebilecek olgunun bâriz bir örneği olarak inceledik. Bu aşamada, ilgili âyetin nüzûl ortamı çerçevesinde değerlendirilmesine güzel bir örnek olduğunu düşündügümüz İbn Âşûr'un yorumlarını özet olarak aktarıp konuyu tamamlayacağız.

İbn Âşûr önce bu âyetteki ifadelerin (daha önce işaret ettiğimiz üzere), 19. ve 20. âyetlerde bahsedilen meleklerle ilgili mevzunun tamamlayıcısı mahiyetinde olduğunu ifade ederek konuya başlamakta ve âyetin anlamının şu şekilde olduğunu ifade etmektedir:

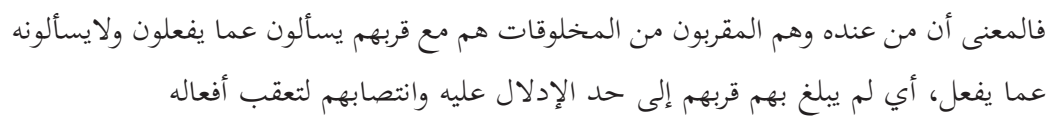

Buna göre âyetin anlamı şöyledir: Allah katında bulunan mukarrabîn (O’na yakın) melekler, mahlûkat içerisinde O’na en yakın varlıklar olmalarına rağmen, Allah'a hesap soramazlar, aksine onlar kendi fiillerinden hesaba çekileceklerdir. Yani onların Allah'a olan yakınlıkları, onları Allah karşısında münakaşa edebilme ya da O’nun fiillerini değerlendirme konumuna yükseltmemiştir.93

Bu yorumun dil bilimi açısından temelini izah etme sadedinde İbn Âşûr, "Allah sorulmaz" ifadesindeki fâilin, yani "Allah’a kim soru soramaz?" soru-

93 İbn Âşûr, et-Tahrîr, XVII, 45. 
sunun cevabının, ifadenin umumi anlam içermesini sağlamak maksadıyla hazfedilmiş olduğunu ve bu sebeple, 19. âyette söz edilen mukarreb (Allah’a yakın) meleklerin bu umumi ifadenin kapsamına girmesinin dil bilimi açısından mümkün olduğunu ifade etmektedir. Yine "lâ yüs'elü ammâ yef'al" ifadesinin aslında "ve hüm yüs'elûn" cümlesi için bir girizgâh mahiyetinde olduğunu, asıl vurgunun "ve hüm yüs'elûn" kısmında, yani müşriklerin medet umdukları meleklerin hesaba çekilecek varlıklar oluşunun ifade edilmesinde olduğunun altını çizdikten sonra, meleklerin hesaba çekilecek olmalarının ifade edilmesinin, onların kulluklarının ifade edilmesinden kinaye olduğunu (فكونهم يسألون كناية عن العبودية) belirten İbn Âşûr, "lâ yüs’elü ammâ yef'al" ifadesindeki "soru”"nun, herhangi bir bilgi öğrenmek ve benzeri maksatlarla sorulan soru anlamında değil, hesaba çekmek, sîgaya çekmek, sorgulamak anlamında soru olduğunu özellikle vurgulamaktadır. Ardında da âyetin temel vurgusunu çok sarih bir şekilde ortaya koyan şu cümleyle değerlendirmelerine son vermektedir:

$$
\begin{aligned}
& \text { وفي هذا إبطال لإلهية المقربين التي زعمها المشركون الذين عبدوالملائكة وزعموهم بنات الله } \\
& \text { تعالى، بطريقة انتفاءخاصية الإله الحق عنهم إذهم يسألون عما يفعلون وشأن الإله أن لا يسأل. }
\end{aligned}
$$

Burada meleklerin Allah’ın kızları olduğunu iddia eden ve onlara ibadet eden müşriklerin dile getirdikleri "meleklerin ulûhiyyeti" iddiasının iptali (geçersizliğinin ifadesi) söz konusudur. Bu iddianın geçersizliği, gerçek ilâhın hususiyeti olan "hesaba çekilmeme" özelliğinin meleklerde bulunmadığının ifade edilmesi suretiyle ortaya konulmaktadır.94

Aslında bu cümle İbn Âşûr'un konuyla ilgili son cümlesi değildir. Bundan sonra, âyetten yola çıkarak, "ilâhî fiillerin tamamının hikmetle yapılmış olduğu ve bunları dikkatlice inceleyip sırlarını anlayan kimsenin bu fiilleri eleştirmesine imkân olmadığı” gibi bir mânanın da çıkarılabileceğini ifade etmektedir. Bu son ifade kelâm tartışmalarına benziyor gibi görünse de, öncesinde âyetin nüzûl ortamındaki temel vurgusunun güçlü bir şekilde ifade edilmiş olması sebebiyle, İbn Âşûr'un tefsiri, kanaatimizce, bu konuda diğer tefsirlerden farklı olma özelliğini korumaktadır. Diğer taraftan buradaki ilgili kelâm tartı̧malarının bütünüyle yersiz ve âyetin fehvâsıyla dahi ilgisiz olduğunu söylemek abartılı olacaktır. Ancak bu tartışmaları âyetle birebir ilişkilendiren ve âyeti tartışmalarda delil olarak kullanan yorumların âyetin nüzûl dönemindeki karşılığını görmezden geldiği ve bir tür anakronizmle muallel olduğu da açıktır.

94 İbn Âşûr, et-Tahrîr, XVII, 46. 


\section{İlâhî Fiillerin Nedenliliği Bağlamında Tefsir-Kelâm İlişskisi}

Tefsir çalışmaları, tarihî süreci boyunca kelâm tartışmalarından büyük ölçüde etkilenmiştir. Bu etkiyi özellikle müteahhirîn dönemi tefsir metinlerinde bâriz şekilde görmek mümkündür. Bu durum belli ölçüde tabii kabul edilebilir olsa da, Kur'an metninin kendi ortamı, metinsel bütünlüğü ve metin dışı (nüzûl) bağlamı içerisinde anlaşılabilmesi için, başkaca değerlendirmelerden mümkün mertebe bağımsız bir perspektiften ele alınması önem taşımaktadır. Bu makalede kelâmın tefsir kitapları üzerindeki etkisi, ilâhî fiillerin nedenliliği konusuyla ilişkilendirilen Enbiyâ sûresinin 23. âyeti özelinde takip edilmiş ve söz konusu âyetin metin içi ve metin dışı bağlam çerçevesinde ifade ettiği anlamın tespiti yapılmış; ardından bu anlamın ilgili kelâm tartışmalarıyla ilişkilendirilmesinin imkânı tartışılmıştır.

Anahtar kelimeler: Tefsir, kelâm, illet, ilâhî fiiller.

\section{Bibliyografya}

Âlûsî, Şehâbeddin Mahmûd, Rûhu'l-meânî fî tefsîri'l-Kur'âni'l-azîm ve's-seb'il-mesânî, I-XXX, Beyrut: Dâru ihyâi't-türâsi'l-Arabî, t.y.

Beyâzîzâde Ahmed Efendi, İşârâtü'l-merâm min ibârâti’l-imâm, haz. Yûsuf Abdürrezzak, Karaçi: Zemzem Publishers, 2004.

Câbirî, M. Âbid, Bünyetüll-akli'l-Arabî, Beyrut: Merkezü Dirâsâti'l-vahdeti'l-Arabiyye, 2007.

Cemel [Süleyman b. Ömer], el-Fütûhâtüll-ilâhiyye bi-tavzîhi tefsîri'l-Celâleyn, I-IV, Kahire: el-Matbaatü'l-âmire eş-şarkiyye, 1303.

Derveze, M. İzzet, et-Tefsîrü'l-hadîs, I-X, Tunus: Dârü'l-garbi'l-İslâmî, 2008.

Dönmez, İbrahim Kâfî, “İllet”, Türkiye Diyanet Vakfi İslâm Ansiklopedisi (DİA), XXII, 117.

Fahreddin er-Râzî, Mefâtîhu'l-gayb: et-Tefsîrül-kebîr, I-XXXII, Beyrut: Dârü’l-fikr, 1981.

Fahreddin er-Râzî, Muhassalü efkâri'l-mütekaddimîn ve'l-müteahhirîn mine'l-ulemâ' ve'l-hükemâ' ve’l-mütekellimîn, haz. Tâhâ Abdürraûf Sa'd, Kahire: Mektebetü'lkülliyyâti'l-Ezheriyye, t.y.

Gazzâlî, el-İktisâd fi'l-i'tikād, haz. İ. Agâh Çubukçu - Hüseyin Atay, Ankara: Ankara Üniversitesi İlâhiyat Fakültesi Vakfı Yayınları, 1962.

....., el-Müstasfâ min ilmi'l-usûl, haz. Nâcî es-Süveyd, I-II, Beyrut: el-Mektebetü'lasriyye, 2009.

Görmez, Mehmet, Sünnet ve Hadisin Anlaşılmasında Metodoloji Sorunu, Ankara: Türkiye Diyanet Vakfı Yayınları, 1997.

Heidegger, Martin, Varlık ve Zaman, çev. Kaan H. Ökten, İstanbul: Agora Kitaplı̆̆g, 2008.

İbn Âşûr, M. Tâhir, et-Tahrîr ve't-tenvîr, I-XXX, Tunus: ed-Dârü't-Tûnisiyye li’n-neşr, 1984. 
İbn Atıyye el-Endelüsî, el-Muharrerüll-vecîz fî tefsîri'l-kitâbi'l-azîz, haz. Abdüsselâm Abdüşşâfî Muhammed, I-V, Beyrut: Dârü’l-kütübi'l-ilmiyye, 1422/2001.

İbn Ebû Şerîf, Kemâleddin, el-Müsâmere bi-şerhil-Müsâyere, Bulak: el-Matbaatülkübrâ el-Emîriyye, 1317.

İbn Hacer el-Askalânî, Fethu'l-bârî, haz. Muhibbüddin el-Hatîb - M. Fuad Abdülbâkī, I-XIII, Beyrut: Dârü'l-ma'rife, 1378/1959.

İbn Haldûn, Mukaddime, haz. Muhammed el-İskenderânî, Beyrut: Dârü'l-kitâbi'lArabî, 2008.

İbn Hazm, el-İhkâm fî usûli’l-ahkâm, haz. Ahmed M. Şâkir, I-VIII, Beyrut: Dârü’lâfâki'l-cedîde, t.y.

İbn Hazm, el-Muhallâ, haz. Ahmed M. Şâkir v.dğr., I-XI, Kahire: İdâretü’t-Tibâati'lMünîriyye, 1347-52.

İbn Hişâm, es-Sîretü’n-nebeviyye, haz. Abdüsselâm Tedmürî, I-IV, Beyrut: Dârü’lkitâbi'l-Arabî, 1990.

İbn Kayyim el-Cevziyye, Şifâül-alîl fî mesâilil-kazâ' ve'l-kader ve'l-hikme ve't-ta'lîl, haz. Mustafa Ebü’n-Nasr eş-Şelebî, I-II, Cidde: Mektebetü’s-sevâdî, 1991.

İbnül-Cevzî, Ebü'l-Ferec, Zâdül-mesîr fî ilmìt-tefsîr, I-IX, Beyrut: el-Mektebü'lİslâmî, 1404/1984.

Kādî Abdülcebbâr, Müteşâbihü’l-Kurân, haz. Adnan M. Zerzûr, I-II, Kahire: Dârü’ttürâs, 1969.

Kādî Abdülcebbâr, Tenzîhü'l-Kur'ân ani'l-metâin, Beyrut: Dârü’n-nehdati'l-hadîse, t.y.

Kerhî, Usûlü̉l-Kerhî. Usûl-i Pezdevî ile birlikte, Karaçi: Mîr Muhammed Kütübhâne, t.y.

Kummî, Ali b. İbrâhim, Tefsîrü’l-Kummî, I-II, Kum: Müessesetü dâri’l-kitâb, 1967.

Kurtubî, Muhammed b. Ahmed, el-Câmi' li-ahkâmi'l-Kur'ân, haz. Abdullah b. Abdülmuhsin et-Türkî v.dğr., I-XXVI, Beyrut: Müessesetü’r-risâle, 1427/2006.

Lalandé, André, Vocabularie: Mevsûatü Laland el-felsefiyye, çev. Halîl Ahmed Halîl, Beyrut-I-III, Paris: Menşûrâtü Uveydât, 2001.

Mâtürîdî, Kitâbüt-Tevhîd, haz. Bekir Topaloğlu - Muhammed Aruçi, İstanbul: İSAM Yayınlar1, 2003.

Mâtürîdî, Te’vîlâtü'l-Kurân, haz. Ahmet Vanlığlu - Bekir Topaloğlu v.dğr., I-XVII, İstanbul: Mizan Yayınevi, 2005-2011.

Mâverdî, en-Nüket ve’l-uyûn, haz. Seyyid b. Abdülmaksî̀d b. Abdürrahîm, I-VI, Beyrut: Dârü'l-kütübi'l-ilmiyye, t.y.

Mukātil b. Süleyman, Tefsîru Mukātil b. Süleymân, haz. Ahmed Ferîd, I-II, Beyrut: Dârü'l-kütübi'l-ilmiyye, 1424/2003.

Nizâmeddin en-Nîsâbûrî, Garâibü'l-Kur'an, haz. Zekeriyyâ Umeyrât, Beyrut: Dârü'lkütübi'l-ilmiyye, 1416/1996. 
Pezdevî, Ebü’l-Yüsr, Usûlüd-dîn, haz. Hans Peter Lins, Kahire: el-Mektebetü'l-Ezheriyye li't-türâs, 2003.

Sâvî, Ahmed b. Muhammed, Haşiyetü̉s-Sâvî alâ tefsîri'l-Celâleyn, Kahire: el-Matbaatü'l-Ezheriyye, 1926.

Semerkandî, Ebü’l-Leys, Bahrül-ulûm, haz. Ali M. Muavvad v.dğr., I-III, Beyrut: Dârü'l-kütübi'l-ilmiyye, 1413/1993.

Serahsî, Şemsüleimme, el-Muharrer fî usûli'l-fikh, Beyrut: Dârü'l-kütübi'l-ilmiyye, $1417 / 1996$.

Seyyid, M. Sâlih, Asâletü ilmi'l-kelâm, Kahire: Dârü’s-sekāfe, 1987.

Sheehan, Thomas, “Dasein”, A Companion to Heidegger, ed. Hubert L. Dreyfus - Mark A. Wrathall, London: Blackwell Publishing, 2005, s. 193-213.

Süyûtî, ed-Dürrü̉l-mensûr, haz. Abdullah b. Abdülmuhsin et-Türkî, I-XVII, Kahire: Dâru Hicr, 1424/2003.

Şehristânî, Nihâyetü'l-ikdâm fî̀ ilmi’l-Kelâm, haz. Alfred Guillame, Bağdat: Mektebetü'lmüsennâ, t.y.

Şelebî, M. Mustafa, Ta 'lîlü̉l-ahkâm, Beyrut: Dârü’n-nehdati'l-Arabiyye, 1981.

Şevkânî, Fethu'l-kadîr, I-V, Beyrut: Âlemü'l-kütüb, t.y.

Şîrâzî, Nâsır Mekârim, el-Emsel fî tefsîri kitâbillâhi'l-münzel, I-XV, Kum: Dârü’n-neşr li-Medreseti'l-İmâm Alî b. Ebî Tâlib, 1992.

Taberî, Muhammed b. Cerîr, Câmiu'l-beyân an te’vîli'l-Kur'ân, haz. Abdülmuhsin etTürkî, I-XXVI, Kahire: Dâru Hicr, 1422/2001.

Tabersî, Mecmau'l-beyân, I-X, Beyrut: Dârü’l-Murtezâ, 2009.

Teftâzânî, Şerhu’l-Makāsıd, haz. Abdurrahman Umeyre, I-V, Beyrut: Âlemü'l-kütüb, 1998.

Tûsî, Ebû Ca'fer, et-Tibyân fî tefsiri'l-Kur'an, haz. Ahmed Habîb Kasîr el-Âmilî, I-X, Beyrut: Dâru ihyâi't-türâsi'l-Arabî, t.y.

Türker, Ömer, “İlâhî Fiillerin Nedenliliği Sorunu: Gazzâlînin Meseleye Yaklaşımı ve Katkısı", İslâm Araştırmaları Dergisi, 17 (2007): 1-24.

Türker, Ömer, “İslâm Metafizik Gelenekleri”, Sabah Ülkesi, 40 (2014): 4.

Türker, Ömer, “Mukaddime’de Aklî İlimler Algısı: İbn Haldûn’un 'Bireysel Yetenekler' Teorisi”, İslâm Araştırmaları Dergisi, 15 (2006): 33-50.

Zebîdî, M. Murtazâ, Tücü'l-arûs min cevâhîril-kāmûs, I-XL, Küveyt: Matbaatü Hükûmeti Küveyt, 1965-2001.

Zeccâc, Meâni'l-Kur'ân ve i'râbüh, haz. Abdülcelîl Şelebî, I-V, Beyrut: Âlemü'l-kütüb, 1408/1988.

Zemahşerî, el-Keşşâf, haz. Âdil Ahmed Abdülmevcûd v.dğr., I-VI, Riyad: Mektebetü’lUbeykân, 1418/1998.

Zencânî, Şehâbeddin, Tahrîcül-fürû‘ ale’l-usûl, haz. M. Edîb Sâlih, Beyrut: Müessesetür-risâle, 1987. 